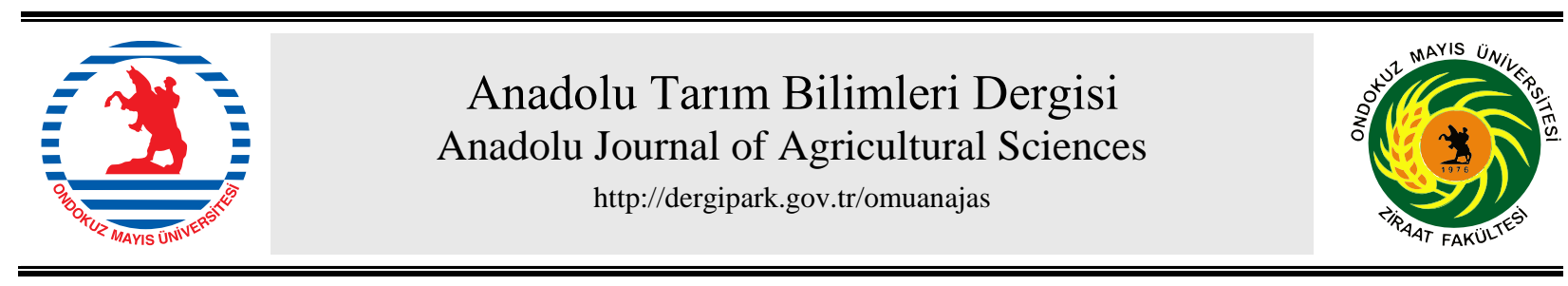

Araştırma/Research

Anadolu Tarım Bilim. Derg./Anadolu J Agr Sci, 35 (2020)

ISSN: 1308-8750 (Print) 1308-8769 (Online)

doi: 10.7161/omuanajas.754035

\title{
Genotip, Verim x Özellik (GVÖ) Kombinasyonunun Biplot Tekniği İle İncelenmesi: Birden Çok Özelliğe Dayalı Genotiplerin Seleksiyonunda Yeni Bir Yaklaşım
}

\author{
DEnver Kendal \\ Mardin Artuklu Üniversitesi, Kızıltepe MYO, Bitkisel ve Hayvansal Üretimi, Tohumculuk Proğramı, Mardin.
}

*Sorumlu yazar/corresponding author: enver21_1@hotmail.com

Geliș/Received 17/06/2020～Kabul/Accepted 05/08/2020

\begin{abstract}
ÖZET
Diyarbakır ilinde yağışa dayalı şartlarda 2011-2012 yetiştirme sezonunda Augmented deneme deseninde ve her birinde 25 parsel bulunan üç blok şeklinde yürütülen çalışmada toplam 8 adet özellik ve genotiplerin yatma gözlemi değerlendirilmiştir. Değerlendirmede; genotip, verim*özellik (GVÖ) analizi kullanılmış ve genotipler, verim*özellik kombinasyon indeksine göre değerlendirilmiştir. İncelenen özellikler bakımından genotipler arasında önemli farklılıklar tespit edilmiștir. Analiz sonuçlarına göre; tane verimi $191-774 \mathrm{~kg}$ / da başaklanma süresi $108-125$ gün, bitki boyu $80-125 \mathrm{~cm}$, hektolitre ağırlığı $62.2-74.7 \mathrm{~kg} / \mathrm{hl}$, bin tane ağırlığı 28.9 - $55.9 \mathrm{~g}$, protein oranı \%13.0-19.5, nişasta oranı \%66.4-70.9, tanedeki nem oranı \%7.9-8.4 arasında değişim göstermiștir. Tane verimi bakımından 2 hat, hektolitre ağırlığı bakımından 27, bin tane ağırlığı bakımından 17, protein oranı bakımından 13 ve nişasta oranı bakımından 5 hat denemede standart olarak kullanılan çeşitlerden daha yüksek değerlere sahip olmuşlardır. Sonuç olarak; çalışmada kullanılan hat sayısının fazla olması durumunda Augmented analiz modeli ve birden çok özelliğe ait verileri değerlendirmek için genotip, verim*özellik kombinasyon analiz modelinin başarılı bir şekilde kullanılabileceğini göstermiştir. GVÖ kombinasyon indeksine göre en üstün olduğu belirlenen 20 adet ileri kademede hat $(1,4,11,17,18,19,21,56,63)$ tespit edilmiş ve bu hatların bir ileri generasyona aktarılması uygun görülmüştür.
\end{abstract}

Investigation of genotype, yield $\times$ traits $(\mathrm{GYT})$ combination with the biplot technique: a new approach to the selection of genotypes based on multiple traits

\section{ABSTRACT}

The most suitable genotypes can only be determined by the effect coefficient that each trait will create, after combining with yield. For this purpose, the study conducted in the Augmented trial pattern in the 2011-2012 growing season in rainy conditions in Diyarbakır province and with the form of 3 blocks with 25 plots each and genotypes were evaluated based on a total of 8 traits and the lodging observations. In the evaluation; genotype, yield ${ }^{\times}$trait (GYT) analysis was used and genotypes were evaluated according to yield ${ }^{\times}$trait combination index. In terms of the characteristics studied, significant differences were detected between the genotypes. According to the results of the analysis; grain yield was changed between 1910 - $7740 \mathrm{~kg} / \mathrm{ha}$, heading time $108-125$ days, plant height $80-125 \mathrm{~cm}$, hectoliter weight 62.2 - $74.7 \mathrm{~kg} / \mathrm{hl}$, thousand grain weight 28.9 - 55.9 g, protein content $13.0-19.5 \%$, starch rate $66.4-70.9 \%$, moisture content in the grain $7.9-8.4 \%$. Two lines in terms of grain yield, 27 line in terms of hectolitre weight, 17 line in terms of grain weight, 13 line in terms of protein ratio and 5 lines in terms of starch ratio had higher values than the varieties used in the experiment. As a result; If the number of lines used in the study is high, it has been shown that Augmented analysis model and genotype, yield* traits combination analysis model can be used successfully to evaluate data of multiple traits. The 20 advanced level lines $(1,4,11,17,18,19,21,56,63)$, which are determined to be the highest according to the GYT combination index, were determined and it was deemed appropriate to
Anahtar Sözcükler:

Arpa,

Seleksiyon,

Diyarbakır,

Kombinasyon,

İndeks.

Keywords:

Barley,

selection,

Diyarbakır,

Combination,

Index. 


\section{Giriş}

Bitki ıslah çalışmaları, verim ve kaliteyi artırmak ve bir çok özellik bakımından daha stabil çeşitleri geliştirmek için yapılmaktadır. Islah çalışmaları kapsamında çoğu zaman denemeler gözlenerek elde edilen veriler eksik olarak değerlendirilmekte ve bu durum hem gereksiz yere fazla zamanımızın harcanmasına hem de maliyetin artmasına karşın ulaşılması beklenen hedefler konusunda yetersiz kalmakta ve islah başarılarını sinırlandırmaktadır(Kendal, 2019). Bu nedenle birden çok gözlemin etkisi verim ile birleştirilerek oluşturulacak genotip, verim*özellik kombinasyon indeksine dayalı seleksiyon, stabil ve üstün genotiplerin seçilmesini sağlayarak ıslah çalışmalarında başarıyı artırmaktadır (Yan ve Frégeau-Reid, 2018).

Islah çalışmalarında, bir özelliğe ait ekonomik önem seviyesi, diğer özelliklere, özellikle de verime olan katkısına bağlıdır. Örneğin, yatmaya dayanıklılık, kısa boyluluk veya erkencilik, sadece yüksek verimle sonuçlandığı durumlarda değerlidir aksi takdirde düşük verimle sonuçlanması durumunda ekonomik değeri yoktur. Benzer şekilde, yüksek kalite özelliğine sahip bir kalite parametresi sadece yüksek verimle birleștiği durumda değerlidir; üstün kaliteye sahip ancak çok düşük verimli bir genotip çeşit adayı olarak kabul görmesi mümkün değildir. Dolayısıyla, bir özelliğin seviyesinin ekonomik değeri yüksek verim ile ilişkilendirildiğinde daha yüksektir. Aslında, bitki ıslahının temel amacı, aynı genotipte yüksek ve güvenilir verimi arzu edilen diğer özellik seviyeleri ile birleştirmektir(Yan ve ark., 2019). Benzer şekilde, agronomik uygulamaların amacı da hem yüksek verime hem de yüksek kaliteye ulaşmaktır. Bu paradigmaya dayanarak, birden çok özelliğe bağlı olarak genotiplerin değerlendirilmesi için verim*özellik kombinasyonu biplot modeli geliştirilmiştir(Yan ve FrégeauReid,2018). Genotip, verim*özellik kombinasyon biplot modeli, verimi diğer hedef özelliklerle birleștirir ve üstünlüklerine bağlı olarak genotipleri grafiksel olarak sıralar ve aynı zamanda genotiplerin güçlü ve zayıf yönlerini sergilemektedir. $\mathrm{Bu}$ nedenle 1slah çalışmalarında seleksiyon başarısını artırarak daha isabetli çeşit adaylarının belirlenmesine olanak sunmaktadır.

Günümüzde çok sayıda çeşit geliştirilmiş ancak arpa yetiştiriciliğini yapan üreticilerin hala çeşit arayışları devam etmektedir. Çevre şartlarına adapte olan verimli aynı zamanda kaliteli çeşitler olduğu gibi bu özelliklere sahip olmayan ve bazı yönleri ile yetersiz olduğu bilinen çeşitlerde vardır (Kendal ve ark., 2016). Bu nedenlerden dolayı birim alanı en iyi değerlendirmek üzere en yüksek ve istenen kalitede ürün elde etmek üzere en uygun çeşit adaylarını belirlemek için arpada çalışmalar hızlı bir şekilde devam etmekte ve ıslah programları buna göre yönlendirilmektedir (Mut ve ark., 2014).

Her hangi bir ilin ekim alanının fazlalı̆g 1 ve dar alanda ekolojik faktörlerin değişimi ıslah çalışmalarını yavaşlattığ önerilmesini gerektirmektedir. Diyarbakır ili çok farklı çevre faktörlerine sahip olup tek tip çeşitlerin yetiştiriciliğinde bazı sorunlarla karşılaşmaktadır. Bazı yerlerde zaman zaman yatma, bazı yerlerde kuraklık, bazı yerlerde sıcaklık stresi bazı yerlerde de toprak profili sorun olabilmektedir. Bu nedenle çeşit adayları çok yönlü araştırılarak tüm özelliklerin ekonomik değeri yüksek verim ile sonuçlanıyorsa çeşit olarak tescil edilmesi gerekmektedir (Kızılgeçi ve ark., 2016).

$\mathrm{Bu}$ çalışmada; 1slah çalışmalarında çok yönlü bir seleksiyon için varyans analiz sonuçlarına ek olarak, genotip, verim*özellik(GVÖ) biplot tekniği ile genotipler(60 adet) incelenen özelliklerin verime olan etkileri de incelenerek erken dönemde etkili bir seleksiyon yapılmışıtır.

\section{Materyal ve Yöntem}

Burası Araştırma, 2011-12 yetiştirme sezonlarında, GAP Uluslararası Tarımsal Araştırma ve Eğitim Merkezi Müdürlüğü (Diyarbakır) uygulama alanında yağışa dayalı şartlarda yürütülmüştür. Araştırmada materyal olarak seleksiyonla elde edilen 60 adet ileri kademede hat ve bölgede geniş alanlarda tercih edilen 5 adet çeşit(Kendal, Altıkat, Samyeli, Şahin 91 ve Vamıkhoca 98) standart olarak kullanılmıştır. Çalışma augmented deneme desenine göre 3 blok şeklinde yürütülmüştür. Çalışmada kullanılan hat/çeşitlere ait bilgiler Çizelge 1' de verilmiştir. Augmented deneme deseninde yürütülen çalışma toplam 3 bloktan oluşmuş ve kontrol çeşitleri, 5 ve katlarına denk gelen parsellerde tesadüf blokları deneme deseninde olduğu gibi tekrarlanmıştır. Denemede kullanılan arpa hatları tekerrürsüz ve sıra ile bloklara dağıtılmıştır. Ulusal(Ege Tarımsal Araştırma Enstitüsü) ve uluslararası(ICARDA) melez programlarından elde edilen 60 adet iki ve altı suralı ileri kademede hat ile birlikte standart olarak bölgede yaygın üretimi yapılan 5 adet tescilli çeşit kullanılmıştır. Buna göre deneme 3 blokta kurulmuş ve her blokta 5 kontrol çeşidi ile birlikte20 arpa hattının yer aldı ̆̆ 1 toplam 25 parselden oluşmuştur 
Çizelge 1. Araştırmanın yürütüldüğü ile ait yıllık ve uzun yıllar sıcaklık değerleri ve yağış miktarları

Table 1. Annual and long years temperature values and precipitation amounts related to the study.

\begin{tabular}{lrrrr}
\hline & \multicolumn{2}{c}{ Ortalama Sicaklık $\left({ }^{0} \mathrm{C}\right)$} & \multicolumn{2}{c}{ Yağış $(\mathrm{mm})$} \\
\cline { 2 - 5 } & $2011-12$ & $\begin{array}{r}\text { Uzun Yıllar } \\
\text { Long Term }\end{array}$ & $2011-12$ & \multicolumn{2}{c}{ Long Term } \\
\hline Eylül/September & 25 & 24.9 & 9.2 & 3.4 \\
Ekim/October & 16.4 & 17.2 & 11.8 & 30.4 \\
Kasim/November & 6.4 & 10.0 & 73.0 & 55.9 \\
Aralık/December & 2.3 & 4.2 & 40.2 & 71.5 \\
Ocak/January & 2.4 & 1.8 & 78.3 & 80.2 \\
Şubat/February & 1.9 & 3.6 & 74.4 & 68.6 \\
Mart/March & 5.1 & 8.1 & 44.0 & 62.2 \\
Nisan/April & 15.2 & 13.8 & 26.2 & 72.1 \\
Mayis/May & 19.6 & 19.3 & 41.0 & 42.9 \\
Haziran/June & 27.7 & 25.9 & 7.0 & 7.1 \\
\hline Toplam/Total & & & 405.1 & 494.3 \\
\hline
\end{tabular}

www:meteor.gov.tr.2013

Araştırmada her parsel için uygun görülen tohumluk miktarı, bin dane ağırlığına göre hesaplanmıştır. Deneme parselleri $1,2 \mathrm{~m}$ x $6 \mathrm{~m}=7,2 \mathrm{~m} 2$ lik alan üzerinde kurulmuştur. Deneme ekimi araştırma için uygun görülen Kasım ayında deneme mibzeri ile m2'ye 450 adet tohum düşecek şekilde yapılmıştır. Taban gübresi olarak 20-20-0 amonyum fosfat gübresi uygun görülmüş ve saf gübre üzerinden 6' şar kg/da (P2O5) ve azot $(\mathrm{N})$ dozu olacak şekilde uygulanmıştır. Amonyum nitrat (\% 33) saf azot üzerinden $6 \mathrm{~kg} / \mathrm{da}$ gelecek şekilde kardeşlenme döneminde uygulanmıştır. Granstar ile illoxan kimyasal ilaçları dar ve geniş yapraklı yabancı otlara karşı karıştırılarak uygulanmıştır. Deneme parselleri, Hege deneme biçerdöveri ile 1,2 x $5=6 \mathrm{~m} 2$ üzerinden hasat edilmiştir. Kalite analizleri NIT(Nearinfrared transmittance) cihazında yapılmıştır.

\subsection{Araştırma yerinin iklim özellikleri}

Denemelerin yürütüldüğü 2011-12 yetiştirme mevsimine ait iklim verileri incelendiğinde; 2011-12 yetiştirme mevsiminde sonbahar ve kış aylarında aylık ortalama sıcaklık değerleri uzun yıllar ortalamalarına göre daha yüksek, ilkbahar gelişme döneminde ise uzun yıllar aylık ortalamalarına göre daha düşük olduğu görülmektedir (Çizelge 1). 2011-12 yetiştirme sezonunda yağış dağılımı (Anonim 1). 2011-12 yetiştirme sezonu yağış miktarı uzun yıllar ortalamasına göre daha düşük ancak yağış dağılımı Nisan ayı hariç diğer aylarda düzenli olarak kaydedilmiştir. Ancak Nisan ayındaki düşük yağış miktarı verim ve kaliteyi etkilemiştir.

\subsection{Verilerin elde edilmesi ve değerlendirilmesi}

Araştırmada; tane verimi, başaklanma süresi, bitki boyu, bin tane ağırlığı, hektolitre ağırlığı, protein oranı, nişasta oranı, tohum nem oranı ve yatma oranı üzerinde incelemeler yapılmıştır. Araştırmadan elde edilen verilerin varyans analizleri Augmented deneme deseninde J.M.P 7.0 (Copyright (c) 2007 SAS Institute Inc.) paket programı kullanılarak yapılmış, önemli bulunan faktör ortalamaları A.Ö.F. testi ile gruplandırılmıştır. Asgari Önemli Farklar, Peterson (1994)'a göre kontrol çeşitlerin birbiriyle karşılaştırılması, aynı blokta yer alan hatların birbiriyle karşılaştırılması, farklı bloklarda yer alan hatların o blok içerisinde birbiriyle karşılaştırılması ve kontrol çeşitlerle hatların karşılaştırılması için ayrı ayrı hesaplanmıştır.

Hatlara ait değerler, bulundukları bloktaki kontrol çeşitlerin o bloktaki ortalamalarının kontrol çeşitlerin genel ortalamalarından olan sapmaları oranında bir düzeltme terimi yardımıyla düzeltilip, düzeltilmiş ortalamaları üzerinden değerlendirilmeye alınmıştır. Asgari Önemli Fark değerleri, Peterson (1994)'a göre aşağıdaki formüllere göre hesaplanarak bulunmuştur. Kontrol çeşitlerin birbiriyle karşılaştırılmasında;

$A O ̈ F=\underline{t \sqrt{ } 2 \mathrm{HKO}}$ Aynı blokta yer alan hatların

$$
\mathrm{b}
$$

düzeltilmiş değerlerinin birbiriyle karşılaştırılmasında;

$\mathrm{AÖF}=\mathrm{t} \sqrt{ } 2 \mathrm{HKO} \quad$ Farklı blokta yer alan hatların düzeltilmiş değerlerinin birbiriyle karşılaştırılmasında;

$\mathrm{AÖF}=\mathrm{t} \sqrt{2}(\mathrm{k}+1) \mathrm{HKO}$

Kontrol çeşitlerin değerleri ile hatların düzeltilmiş değerlerinin karşılaştırılmasında;

$\mathrm{AÖF}=\underline{\mathrm{t}} \sqrt{(\mathrm{b}+1)(\mathrm{k}+1) \mathrm{HKO}}$

bk formülleri kullanılmıştır.

Burada, Asgari Önemli Fark1, HKO kontrol çeşitlerin incelenen özelliklerine ait varyans analizi tablosundaki Hatanın Kareler Ortalamasını, b blok sayısını, k kontrol çeşit sayısını, t hata serbestlik derecesi olan 0.05 düzeyindeki tablo $t$ değerini ifade etmektedir(Kılıç ve ark., 2012).

Biplot analizinde; genotip, verim*özellik(GVÖ) modeli kullanılmıştır. $\mathrm{Bu}$ model birçok adımdan oluşmaktadır. Birincisi, iki yönlü genotip* özelik(GÖ) tablosunu genotip, verim*özellik(GVÖ) tablosuna dönüştürülmüş, ikincisi, her bir verim*özellik kombinasyonu ile GVÖ tablosu standart hale getirilmiş, 
üçüncüsü verim-özellik kombinasyonlarına nispi önemlerine göre uygun etki oranları belirlenmiş ve son olarak, her genotip için ağırlıklı verim-özellik kombinasyonlarının ortalaması olan GVÖ indeksi hesaplanmıştır. Biplot analizleri GenStat 12 programı kullanılarak yapılmış ve şekiller elde edilmiştir. GVÖ indeksi genel üstünlüğün bir ölçüsü olup genotiplerin sıralanmasında kullanılmıştır (Kendal, 2019) GVÖ verileri Yan ve Frégeau-Reid, (2018)’ uygun gördükleri formül kullanılarak elde edilmiştir.

$$
P_{i j}=\frac{T_{i j}-\bar{T}_{j}}{s_{j}},
$$

Formül: $\quad s_{j} \quad \mathrm{Pij}$, genotipin standart değeri, Tij genotipin orijinal değerleri(i özellik veya verim-özellik kombinasyonunu, $\mathrm{j}$ ise genotip-özellik veya genotip, verim-özellik tablosundaki orijinal değerleri, Tj, özellik veya verim-özellik kombinasyonu için genotiplerin ortalamasını, sj özellik veya verimözellik kombinasyonu için standart sapma değerlerini belirtmektedir. metin biçiminde yazılacaktır

\section{Bulgular ve Tartışma}

Araştırmadan elde edilen değerler Augmented deneme deseninde analiz edilmiş çeşitler; kendi aralarında karşılaştıııldığı gibi, kontrol çeşitlerin varyans analizinden elde edilen hata kareler ortalamas1 kullanılarak yani hatların değerleri de kendi aralarında değerlendirilmiş ve kontrol çeşitlerle istatistiki anlamda bir farklılığın olup olmadığı araştırılmıştır. İncelenen özellikler bakımından genotiplerin ortalama değerleri, F değerleri, farklılık gruplandırmaları ve kareler ortalama değerleri Çizelge 2.'de verilmiştir. Araştırmadan elde edilen verilerin varyans analiz sonuçlarına göre; tane verimi, başaklanma süresi, protein oranı ve nişasta oranı bakımından genotipler arasında \% 0.01, hektolitre ağırlığ bakımından \% 0.05 oranında istatiksel olarak önemli farklılık tespit edilmiştir. Bitki boyu, bin tane ağırlığ arasında herhangi bir farklılık tespit edilememiştir (Çizelge 2).

Çizelge 2. Kareler ortalamasına ait varyan analiz tablosu

Table 2. Analysis of variance of the average of squares

\begin{tabular}{lccccccccc}
\hline Varyasyon K. & SD & TV & BS & BB & BTA & HL & PO & NO & TN \\
Variation S. & $D S$ & $G Y$ & $H T$ & $P H$ & $T G W$ & $H W$ & $P C$ & $S C$ & $G M$ \\
\hline Model/Model & 66 & 924501.4 & 831.2 & 4695.0 & 2619.0 & 533.2 & 171.0 & 99.1 & 1.02 \\
Tekerrür/Blok & 2 & 21046.3 & 1.9 & 40.7 & 36.9 & 0.7 & 0.3 & 0.1 & 0.00 \\
Genotip/genotypes & 64 & $889431.8^{* *}$ & $810.3^{* *}$ & 4551.4 öd & 2511.8 öd & $489.9^{*}$ & $165.2^{* *}$ & $96.3^{* *}$ & 1.0 öd \\
Hata/Error & 7 & 945209.7 & 834.6 & 4900.3 & 2823.4 & 539.6 & 1.2 & 0.9 & 0.05 \\
\hline AÖF/LSD $(0.05)$ & & 182 & 2.3 & 18 & 18.1 & 3.18 & 1.36 & 1.17 & 0.3 \\
\hline DK/CV $(\%)$ & & 9.3 & 0.6 & 5.1 & 12.1 & 1.38 & 2.6 & 0.5 & 1.0 \\
\hline
\end{tabular}

AÖF: Asgari Önemli Fark(least sig.), DK:Değişim Katsayısı /Degree of Freedom, ** 0.01 düzeyinde önemli/sig, * 0.05 düzeyinde önemli/sig. Öd:önemli değil/not sig.

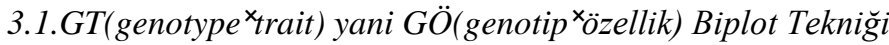

Bu teknikle Çizelge 3’teki veriler kullanılarak dört ayrı şekil oluşturulmuştur.

Çizelge 3. Genotiplerin pedigrileri ve incelenen özelliklerine ait ortalamalar ve önemlilik durumları Table 3. The pedigrees of the genotypes and the average and significance states of the examined properties

\begin{tabular}{|c|c|c|c|c|c|c|c|c|c|c|c|c|}
\hline \multirow[t]{2}{*}{ No } & $\begin{array}{c}\text { Çeşit veya Pedigri } \\
\text { Cultivars and Pedigree }\end{array}$ & \multirow{2}{*}{$\begin{array}{c}\text { Baş. } \\
\text { Tipi } \\
\text { ST }\end{array}$} & \multirow{2}{*}{$\begin{array}{l}\text { Der. } \\
(1-5) \\
\text { Scor } \\
(1-5)\end{array}$} & \multirow{2}{*}{$\begin{array}{c}\text { TV } \\
\text { GY } \\
\left(\mathrm{kg} / \mathrm{ha}^{-1}\right)\end{array}$} & \multirow{2}{*}{$\begin{array}{c}\text { BS } \\
\text { (gün) } \\
\text { HT } \\
\text { (date) } \\
\end{array}$} & \multirow{2}{*}{$\begin{array}{l}\mathrm{BB} \\
(\mathrm{cm}) \\
\mathrm{PH} \\
(\mathrm{cm})\end{array}$} & \multirow{2}{*}{\multicolumn{2}{|c|}{$\begin{array}{l}\text { BTA HL } \\
(\%)(\%) \\
\text { TGW HW } \\
(\%)(\%)\end{array}$}} & \multirow{2}{*}{$\begin{array}{l}\mathrm{PO} \\
(\%) \\
\mathrm{PC} \\
(\%) \\
\end{array}$} & \multirow{2}{*}{$\begin{array}{l}\text { NO } \\
(\%) \\
\text { SC } \\
(\%) \\
\end{array}$} & \multirow{2}{*}{$\begin{array}{l}\text { TN } \\
\text { (\%) } \\
\text { GM } \\
(\%)\end{array}$} & \multirow{2}{*}{$\begin{array}{l}\text { Yat } \\
\text { (\%) } \\
\text { Lod } \\
(\%)\end{array}$} \\
\hline & & & & & & & & & & & & \\
\hline 01 & 2762/BC/3/11012.2/ --SEA003-07-0SD-0SD-2SD-0SD & $6 \mathrm{sir}$ & 5 & $749^{\text {af }}$ & $116^{\mathrm{fk}}$ & 110 & 44.4 & $68.5^{1 y}$ & 13.9 & $70.2^{\mathrm{ag}}$ & 8.1 & 1 \\
\hline 02 & NUTANS 752/P-2/... SEA003-12-0SD-0SD-3SD-0SD & $6 \mathrm{sir}$ & 5 & $631^{\mathrm{ag}}$ & $120^{\mathrm{bc}}$ & 110 & 28.9 & $63.7^{\mathrm{z}}$ & $14.7^{\mathrm{m}}$ & $70.2^{\mathrm{ag}}$ & 8.1 & 5 \\
\hline 03 & ICB-100059//-- SEA003-13-0SD-0SD-2S-0SD & $2 \mathrm{sir}$ & 4 & $540^{\mathrm{hw}}$ & $118^{\mathrm{cg}}$ & 105 & 50.4 & $68.9^{1 \mathrm{x}}$ & $15.5^{\mathrm{gr}}$ & $70.0^{\mathrm{ah}}$ & 8.1 & 5 \\
\hline 04 & CEN-B/2*CA-192.... SEA003-23-0SD-0SD-2SD-0SD & $6 \mathrm{sir}$ & 5 & $728^{\mathrm{a} 1}$ & $118^{\mathrm{cg}}$ & 115 & 44.9 & $68.6^{\mathrm{jy}}$ & $13.3^{z}$ & $70.8^{\mathrm{ab}}$ & 8.3 & 2 \\
\hline 06 & CEN-B/2*CA-192//.. SEA003-23-0SD-0SD-4SD-0SD & $6 \mathrm{sir}$ & 5 & $580^{\mathrm{du}}$ & $117^{\mathrm{d} \mathrm{t}}$ & 95 & 43.6 & $62.2^{\mathrm{z}}$ & $15.8^{\text {fo }}$ & $67.7^{\mathrm{gv}}$ & 7.9 & 8 \\
\hline 07 & CEN-B/2*CA-192//.. SEA003-23-0SD-0SD-5SD-0SD & $6 \mathrm{sir}$ & 5 & $384^{\mathrm{wx}}$ & $117^{\mathrm{d} 1}$ & 110 & 51.6 & $69.3^{\mathrm{g}}$ & $\mathrm{w} 17.4^{\mathrm{be}}$ & e $67.3^{\text {tv }}$ & 8.0 & 6 \\
\hline 08 & CEN-B/2*CA-192//.. SEA003-23-0SD-0SD-6SD-0SD & $6 \mathrm{sir}$ & 5 & $448^{\mathrm{rw}}$ & $117^{\mathrm{d} 1}$ & 105 & 52.1 & $69.1^{\mathrm{h}>}$ & $x 16.7$ & h $67.8^{\mathrm{gv}}$ & 8.1 & 5 \\
\hline 09 & CEN-B/2*CA-192//.. SEA003-23-0SD-0SD-7SD-0SD & $6 \mathrm{sir}$ & 5 & $594^{\mathrm{du}}$ & $115^{\mathrm{hm}}$ & 105 & 52.1 & $71.1^{\mathrm{bl}}$ & $\mathrm{m} 14.9^{\mathrm{kx}}$ & ${ }^{x} 69.5^{\mathrm{cn}}$ & 8.3 & 3 \\
\hline
\end{tabular}


11 CEN-B/2*CA-I92//.. SEA003-23-0SD-0SD-8SD-0SD

12 ARRAYAN/OLMO//.. SEA003-28-0SD-3SD-0SD

13 HARMA-02//...SEA003-32-0SD-0SD-1SD-0SD

14 Expro0057/7/ -... SEA003-42-0SD-0SD-1SD-0SD

16 Expro0057/..SEA003-42-0SD-0SD-2SD-0SD

17 Slad/4/HB854/3/ ... SEA003-47-0SD-0SD-1SD-0SD

18 PLAISANT / / /. SEA003-54-0SD-0SD-2SD-0SD

19 PLAISANT /.. SEA003-54-0SD-0SD-0SD-3SD-0SD

21 PLAISANT /SCIO/..SEA003-54-0SD-0SD-0SD-5SD

22 CI 10035/CI1042// SEA-003-01-0SD-0SD-1SD-0SD

23 PATTY/3/WEEAH 11..SEA003-16-0SD-1SD-0SD

24 PATTY/3/....SEA003-16-0SD-0SD-3SD-0SD-0SD

26 PATTY/3/..SEA003-16-0SD-0SD-4SD-0SD

27 PATTY/3/WEEAH .. SEA003-17-0SD-0SD-1SD-0SD

28 PATTY/3/WEEAH ..SEA003-17-0SD-0SD-3SD-0SD

29 PATTY/3/WEEAH ...SEA003-18-0SD-0SD-5SD-0SD

31 PATTY/3/WEEAH --SEA003-18-0SD-0SD-7SD-0SD

32 PATTY/3/ 16/.. SEA003-20-0SD-0SD-2SD-0SD

33 Rod/Scala/4/..SEA-003-23-0S-0S-1SD-0SD

$34 \mathrm{Rod} / \mathrm{Scala} / 4 / . . \mathrm{SEA}-003-23-0 \mathrm{~S}-0 \mathrm{~S}-2 \mathrm{SD}-0 \mathrm{SD}$

36 Rod/Scala/4/..SEA-003-23-0S-0S-3SD-0SD

37 Birlik-1 ICB03-1788-0AP-6AP-0AP-0SD

38 Birlik-1/3/ ...ICB03-1791-0AP-10AP-0AP-0SD

39 Birlik-1/4/..ICB03-1830-0AP-8AP-0AP-0SD

41 AFG-ICB-123459/..ICB03-2441-0AP-1AP-0AP-0SD

42 K-334/Sararood-ICB00-1973-15AP-6AP-0AP-0SD

43 Arta//Sonata/Arta..ICB04-0261-0AP-9AP-0AP-0SD

44 Roho/4/Zanbaka/..ICB04-0371-0AP-3AP-0AP-0SD

46 Tadmor/Tea..ICB04-0388-0AP-28AP-0AP-0SD

47 Carina/WI2291//....ICB02-1072-0AP-9AP-0AP-0SD

48 Cerise/....... ICB97-0402-0AP-8AP-6TR-11AP-0SD

49 Cerise/..ICB97-0402-0AP-11AP-15TR-5AP-0AP-0SD

51 Carina/WI2291//..ICB02-0989-29AP-0AP-0SD

52 SLB05-096/...ICB00-0699-0AP-19AP-0AP

53 ArabiAbiad/.. 0812-0AP-5AP-0AP-0SD

54 Tipper/Moroc9-75..ICB93-1133-0AP-10AP-0AP-0SD

56 ER/Apm/.ICB89-0524-4BO-1AP-0AP-3AP-0AP-0SD

57 Nadawa/Rhn-ICB03-0550-0AP-9AP-0AP-0SD

58 Arizona5908/ ....... ICB03-0043-0AP-4AP-0AP

59 Fedora/Expres--ICB99-0045-13AP-8AP-0AP-0SD

61 Bugar/K-..ICBH94-0458-0AP-0AP-7AP-8AP-0AP

62 Lignee131/ . - ICB00-1676-0AP-3AP-0AP-0SD

63 СWB...ICBH93-0111-0AP-5AP-0AP-10AP-0AP-0SD

64 Pamir-009/.ICBH99-0034-0AP-13AP-0AP-0SD

66 Xemus/3/.. ICBH99-0235-0AP-18AP-0AP-0SD

67 Sadik-01/5//.. ICB00-1512-0AP-7AP-0AP-0SD

68 Pamir-168//..ICB00-1668-0AP-1AP-0A

69 Pamir-168/4/..ICBH99-0071-0AP-50AP-0AP-0SD

\begin{tabular}{|c|c|c|c|c|c|}
\hline sir & & $807^{\mathrm{ab}}$ & $118^{\mathrm{cg}} 107$ & $50.469 .7^{\mathrm{fw}} 13.1^{\mathrm{z}} \quad 70.8^{\mathrm{ab}}$ & 8.3 \\
\hline sir & & $608^{c t}$ & $112^{\text {nr }} 113$ & $55.173 .1^{\text {ae }} 14.8^{\mathrm{ky}} 69.1^{\mathrm{ep}}$ & 8.2 \\
\hline Sir & & $555^{g v}$ & $119^{\text {се }} 110$ & $40.469 .7^{\mathrm{fw}} 14.2^{\mathrm{pz}} 70.5^{\mathrm{ad}}$ & 8.1 \\
\hline sir & & $712^{\mathrm{aj}}$ & $115^{\mathrm{hm}} 115$ & $37.6 \quad 67.9^{\mathrm{nz}} 13.0^{\mathrm{z}} \quad 70.2^{\mathrm{ag}}$ & 8.3 \\
\hline sir & & $584^{\mathrm{du}}$ & $122^{\mathrm{b}} 100$ & $45.162 .2^{\mathrm{z}} 14.5^{\mathrm{nz}} 69.7^{\mathrm{al}}$ & 7.9 \\
\hline sir & 5 & $747^{\text {af }}$ & $118^{\mathrm{cg}} 125$ & $52.668 .0^{\mathrm{lz}} 13.5^{\mathrm{yz}} 70.5^{\mathrm{ad}}$ & 8.2 \\
\hline sir & & $760^{\mathrm{af}}$ & $115^{\mathrm{hm}} 100$ & $42.166 .6^{\mathrm{uz}} 14.0^{\mathrm{sz}} 69.7^{\mathrm{al}}$ & 8.3 \\
\hline sir & & $787^{\mathrm{ac}}$ & $110^{\mathrm{rs}} 95$ & $32.968 .4^{\text {ly }} 15.1^{\text {iv }} 68.1^{\text {ou }}$ & 8.3 \\
\hline Sir & 5 & $639^{\mathrm{ag}}$ & $114^{\text {jo }} 100$ & $52.672 .0^{\mathrm{ak}} 16.1^{\mathrm{el}} 68.5^{\mathrm{mu}}$ & 8.1 \\
\hline sir & 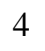 & $673^{\text {an }}$ & $111^{\text {pr }} 98$ & $52.470 .2^{\mathrm{ct}} 16.3^{\mathrm{dk}} 68.6^{\mathrm{s}}$ & 8.2 \\
\hline sir & & $507^{\mathrm{kw}}$ & $111^{\text {pr }} 100$ & $53.169 .3^{\mathrm{ev}} 18.5^{\mathrm{ab}} 67.6^{\mathrm{rw}}$ & 8.2 \\
\hline Sir & 4 & $505^{\mathrm{kw}}$ & $111^{\text {pr }} 105$ & $54.667 .1^{\mathrm{aj}} 18.5^{\mathrm{ab}} 67.7^{\mathrm{gv}}$ & 7.9 \\
\hline Sir & & $68^{\text {ow }}$ & $108^{s} 97$ & $41.666 .3^{\mathrm{ag}} 18.2^{\mathrm{ab}} 67.5^{\mathrm{sw}}$ & 8.0 \\
\hline sir & 5 & $547^{\mathrm{dv}}$ & $114^{\text {jn }} 102$ & $32.470 .2^{\mathrm{ct}} 13.5^{\mathrm{wz}} 70.9^{\mathrm{a}}$ & 8.4 \\
\hline Sir & 5 & $98^{\mathrm{mw}}$ & $117^{\text {dh }} 107$ & $37.969 .8^{\mathrm{ev}} 15.1^{\mathrm{iu}} 68.2^{\mathrm{ou}}$ & 8.2 \\
\hline & & & $117^{\text {dh }} 102$ & $5.672 .0^{\mathrm{aj}} 17.9^{\mathrm{bc}} 68.7^{\mathrm{Ir}}$ & \\
\hline & & & $113^{\lg } 102$ & $39.972 .6^{\text {ag }} 15.1^{1 \mathrm{u}} 70.2^{\mathrm{af}}$ & \\
\hline & & $687^{\mathrm{al}}$ & $116^{\mathrm{fj}} 102$ & $40.469 .1^{\mathrm{hw}} 13.0^{\mathrm{z}} \quad 70.4^{\mathrm{af}}$ & 8.1 \\
\hline S1r & & $606^{\text {br }}$ & $110^{\text {rs }} 107$ & $43.472 .6^{\mathrm{ag}} 13.7^{\mathrm{vz}} 70.7^{\mathrm{ac}}$ & \\
\hline Sir & & $643^{\mathrm{ar}}$ & $112^{\mathrm{nr}} 107$ & $41.972 .8^{\mathrm{af}} 14.0^{\mathrm{gz}} 70.1^{\mathrm{ag}}$ & 8.3 \\
\hline & & $96^{\mathrm{cs}}$ & $114^{\mathrm{jn}} 107$ & $41.672 .9^{\text {af }} 14.9^{\text {jy }} 70.5^{\text {ad }}$ & 8.2 \\
\hline Sir & 4 & $191^{\mathrm{x}}$ & $110^{\text {rs }} 107$ & $38.671 .0^{\text {bn }} 17.8^{\text {bc }} 68.6^{\text {sk }}$ & 8.1 \\
\hline sir & 4 & $40^{w x}$ & $110^{\text {rs }} 117$ & $55.967 .1^{\mathrm{tz}} 17.7^{\mathrm{bd}} 67.5^{\mathrm{sw}}$ & 8.1 \\
\hline sir & 4 & $24^{\mathrm{hv}}$ & $117^{\text {dh }} 122$ & $55.670 .5^{\mathrm{cg}} 15.4^{\mathrm{gs}} 69.9^{\mathrm{aj}}$ & 8.1 \\
\hline $6 \mathrm{sur}$ & 4 & $76^{\mathrm{nw}}$ & $112^{\mathrm{nr}} 122$ & $31.667 .2^{\text {sz }} 14.9^{\text {jy }} 68.3^{\text {nu }}$ & 8.3 \\
\hline & 5 & & $117^{\text {dh }} 107$ & $50.670 .7^{\text {ср }} 16.1^{\text {em } 69.0^{\text {gq }}}$ & 8.1 \\
\hline & & $8^{\mathrm{tw}}$ & $116^{\mathrm{fj}} 117$ & $38.168 .5^{\mathrm{ky}} 16.2^{\mathrm{el}} 68.5^{\mathrm{lu}}$ & 8.0 \\
\hline sir & 3 & $10^{\mathrm{tw}}$ & $112^{\mathrm{nr}} 82$ & $38.669 .3^{\mathrm{hw}} 17.2^{\mathrm{bf}} 67.6^{\mathrm{rv}}$ & 8.1 \\
\hline sir & 4 & $59^{q w}$ & $112^{\mathrm{nr}} 102$ & $43.470 .4^{\text {cr }} 16.7^{\text {ch }} 66.8^{\mathrm{vw}}$ & 8.2 \\
\hline & 4 & $475^{\mathrm{nw}}$ & $112^{\mathrm{nr}} 102$ & $40.973 .3^{\text {ad }} 16.4^{\text {dj }} 68.2^{o}$ & 8.2 \\
\hline & 4 & $66^{\mathrm{vx}}$ & $118^{\mathrm{cf}} 107$ & $38.171 .3^{\text {an }} 19.5^{a} 66.4^{w}$ & 7.9 \\
\hline & 4 & $422^{\mathrm{sw}}$ & $111^{\mathrm{pr}} 107$ & $42.967 .1^{\mathrm{tz}} 17.8^{\mathrm{bc}} 66.4^{\mathrm{w}}$ & 8.0 \\
\hline & 4 & $21^{\text {as }}$ & $112^{\mathrm{mr}} 98$ & $37.769 .7^{\mathrm{ew}} 16.1^{\mathrm{em}} 67.8^{\mathrm{gv}}$ & 8.1 \\
\hline sir & 4 & $20^{\text {as }}$ & $111^{\mathrm{pr}} 103$ & $43.770 .1^{\text {du }} 15.0^{\text {1y }} 69.2^{\text {fo }}$ & 8.1 \\
\hline sir & 4 & $28^{1 \mathrm{w}}$ & $112^{\mathrm{mr}} 118$ & $41.470 .4^{\mathrm{ct}} 16.0^{\mathrm{en}} 67.5^{\mathrm{rw}}$ & 8.2 \\
\hline Sir & 5 & $65^{\mathrm{dv}}$ & $113^{\mathrm{kp}} 98$ & $40.974 .7^{\mathrm{a}} 15.9^{\text {fo }} 68.3^{\text {ou }}$ & \\
\hline & 5 & $90^{\mathrm{am}}$ & $113^{\mathrm{kp}} 108$ & $54.970 .9^{\text {co }} 16.0^{\text {en }} 69.2^{\text {fo }}$ & 8.2 \\
\hline & 4 & $555^{\mathrm{dv}}$ & $117^{\text {ch }} 103$ & $46.766 .6^{\mathrm{vz}} 13.9^{\mathrm{uz}} 69.6^{\mathrm{bm}}$ & 8.1 \\
\hline $6 \mathrm{sir}$ & 5 & $12^{\mathrm{cw}}$ & $112^{\mathrm{mr}} 103$ & $45.967 .0^{\mathrm{rz}} 16.2^{\mathrm{em}} 67.9^{\mathrm{pv}}$ & 8.2 \\
\hline & 4 & $634^{\mathrm{ar}}$ & $117^{\text {ch }} 108$ & $48.265 .6^{\mathrm{xz}} 13.9^{\mathrm{uz}} 69.5^{\mathrm{cn}}$ & 8.1 \\
\hline $6 \mathrm{sir}$ & 4 & $588^{\mathrm{ct}}$ & $115^{\mathrm{gl}} 118$ & $37.269 .9^{\text {du }} 15.5^{\text {gs }} 69.7^{\mathrm{am}}$ & 8.2 \\
\hline & 5 & $470^{\mathrm{pw}}$ & $117^{\text {ch }} 113$ & $40.769 .8^{\mathrm{ew}} 16.3^{\mathrm{dk}} 69.5^{\mathrm{cn}}$ & 8.1 \\
\hline & 5 & $689^{\mathrm{am}}$ & $117^{\text {ch }} 108$ & $48.272 .4^{\mathrm{ar}} 15.8^{\text {fo }} 70.4^{\mathrm{ae}}$ & 8.3 \\
\hline $2 \mathrm{sir}$ & 5 & $626^{\mathrm{ar}}$ & $115^{\mathrm{gl}} 108$ & $45.274 .4^{\mathrm{ab}} 15.4^{\mathrm{ht}} 70.1^{\mathrm{ag}}$ & 8.3 \\
\hline & 5 & $659^{\text {ao }}$ & $117^{\text {ch }} 98$ & $42.762 .5^{z} 14.1^{\mathrm{rz}} 69.9^{\mathrm{aj}}$ & 8.2 \\
\hline $6 \mathrm{sir}$ & 5 & $598^{\mathrm{ct}}$ & $116^{\mathrm{ej}} 93$ & $44.968 .1^{\text {ly }} 15.11^{\mathrm{v}} 69.2^{\mathrm{fo}}$ & 8.2 \\
\hline & 5 & $714^{\text {ah }}$ & $118^{\mathrm{cf}} 98$ & $47.764 .6^{\mathrm{z}} \quad 16.1^{\mathrm{em}} 68.4^{\mathrm{nu}}$ & 7.9 \\
\hline & & $609^{b s}$ & $119^{\text {bd }} 103$ & $39.469 .5^{\mathrm{fw}} 14.6^{\mathrm{oz}} 69.9^{\mathrm{aj}}$ & 8.2 \\
\hline
\end{tabular}




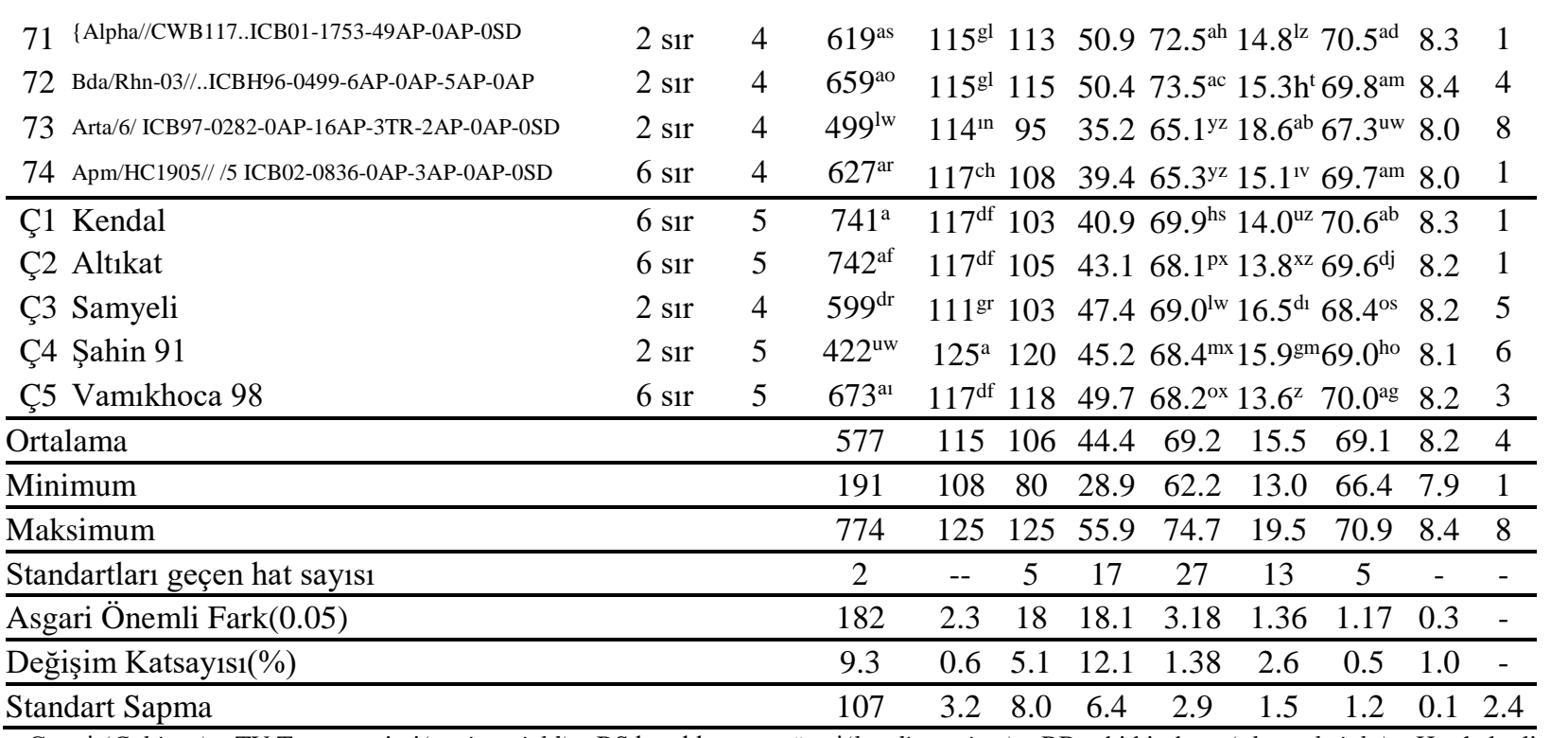

Ç:çeşit(Cultivar), TV:Tane verimi(grain yield), BS:başaklanma süresi(heading time), BB: bitki boyu(plant height), H: hektolitre ağırlığı(hectoliter weight), BTA: bin tane ağırlığı(thousand grain weight), PO: protein oranı(protein content), NO: nişasta oranı (starch content), TN: tane nem oranı(grain moister), YAT: yatma(lodging) (1-9,1: yatmayan, 9 en fazla yatma gösteren), Der(scor)(1-5, 1:kötü, 5 en iyi)

Şekil 1A: araştırmada incelenen özellikler arasındaki ilişki ile genotip özellik ilişkisi, Şekil 1B: özelliklerin gruplandırılması ve genotipler ile özelliklerin sektör ilişkisi, Şekil 1C: özelliklere ait verilerin ortalaması bakımından genotiplerin stabilitesi, Şekil 1D: özelliklerin ortalama verileri üzerinden oluşturulan temsili ideal merkeze göre genotip veya özellikler değerlendirilmektedir (Kılıç ve ark., 2018; Kabak ve Akçura, 2017; Kızılgeçi ve ark., 2019; Oral ve ark., 2019). Temel Bileşen Analizi iki boyutlu PCA skoru toplam varyasyonun, \% 55.15'ini oluştururken, PCI \% 37.21 'lik ve PC2 \% 17.94' lük paya sahip olmuştur. Şekil 1A: Tablo 3 verileri ile oluşturulan bu şekil birkaç maddede açiklanabilmektedir. (Yan and Rjcan, 2002) 1) İki özelliğin vektörleri arasındaki açının kosinüsü, yaklaşık olarak bu iki özelliğin arasındaki Pearson korelasyonudur. Yani, $90^{\circ}$ 'den küçük bir açı pozitif korelasyonu, $90^{\circ}$ den büyük bir açı negatif korelasyonu ve $90^{\circ}$ 'lik bir açı ise sıfır korelasyonu göstermektedir.

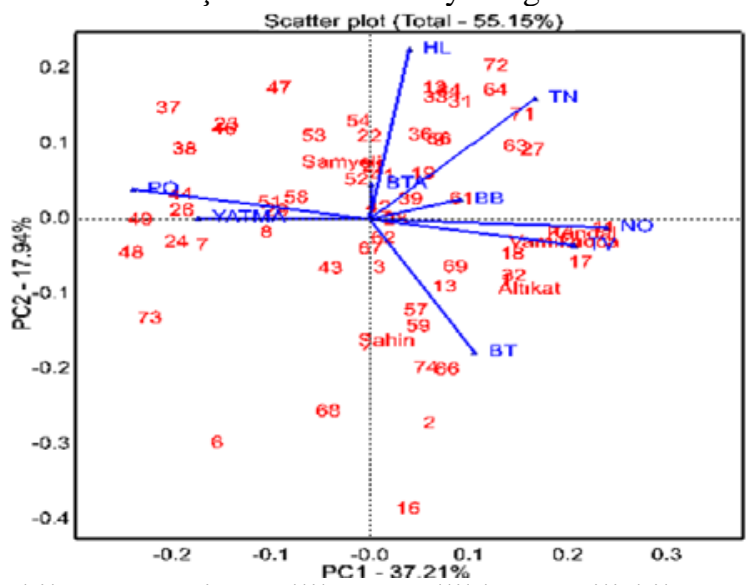

Şekil 1A:Genotip-özellik ve özelliklerarası ilişkiler
Figure 1A: The genotype-traits and the interrelationships of traits

2) bir genotip ile özellik arasındaki açı, özellik için genotipin nispi seviyesini gösterir. Bu nedenle, dar bir açı, genotipin özellik için ortalamanın üzerinde olduğunu gösterir; geniş bir açı, genotipin özellik için ortalamanın altında olduğunu gösterir ve dik açı genotipin özellik için ortalama değere sahip olduğunu gösterir. 3) bir özelliğin vektör uzunluğu (yani, biplot başlangı̨̧ noktasına olan mesafe), özelliğin biplotta ne kadar iyi temsil edildiğini gösterir; herhangi bir özelliğe ait kısa bir vektör, genotipler boyunca o özelliğin varyasyonunun ya değeri küçük ya da diğer özelliklerle korelasyonunun zayıf olmasından ya da eksikliğinden dolayı biplotta iyi sergilenemediğini gösterir. Ayrıca, biplot varyasyonun düşük bir yüzdeliğini temsil ediyorsa ortaya çıkabilir (Şekil 1'deki GÖ biplot varyasyonun sadece \% 55.15'ini temsil etmektedir). 4) Bir genotipin merkezden uzaklığı veya yakınlığı, tüm özellikler için uygun olup olmadığını veya bir özellik bakımından güçlü veya zayıf yönleri olup olmadığını göstermektedir. Bu şekilde (Şekil 1A) TV ile Yatma ve PO ile negatif bir korelasyona girdiği için yatmanın ve protein oranının yükselmesi durumunda verimin düştüğünü göstermektedir. Bunların aksine, TV ile NO arasında ise yüksek bir pozitif ilişki olduğunu göstermektedir. Öbür taraftan BB ve BTA kısa bir vektöre sahip olduklarından bunların varyasyon içerisindeki etki payları düşüktür yani verime olan etkileri kısmidir. BT, HL ve TN uzun vektöre sahip olup bunların varyasyondaki etkileri yüksek ancak TV ile çok düşük ve pozitif bir korelasyona girmişlerdir. Genotip-özellik ilişkisini değerlendirdiğimizde ise 48 ve 49 nolu genotiplerin yüksek oranda yatma gösterdikleri aynı zamanda yüksek PO değerine sahip oldukları, 2 ve 16 nolu genotiplerin çok geçci hatlar oldukları, 17 ve 18 
nolu hatlar ile Kendal çeşidinin yüksek verime ve nişasta oranına sahip oldukları, 62 ve 74 nolu hatların yüksek tane nemine ve hektolitre ağırlıklarına sahip oldukları, 12, 62, 39 ve 3 nolu hatların tüm özelikler bakımından ortalama değerlere sahip oldukları tespit edilmiştir. Görüldüğü gibi GT yani GÖ biplot tekniği bir genotipin sadece özellikler bakımından durumunu sergiler ancak bir genotipin tam anlamıyla seçilip seçilmeyeceği konusunda bize net bir fikir verememektedir, seleksiyon için GYT yani GVÖ tekniğinin daha uygun olduğu aşağıda belirtilmiştir.

Özelliklerin gruplandırılması ve genotipler ile özelliklerin sektörlere göre ilişkisi Şekil 1B'de gösterilmiştir.

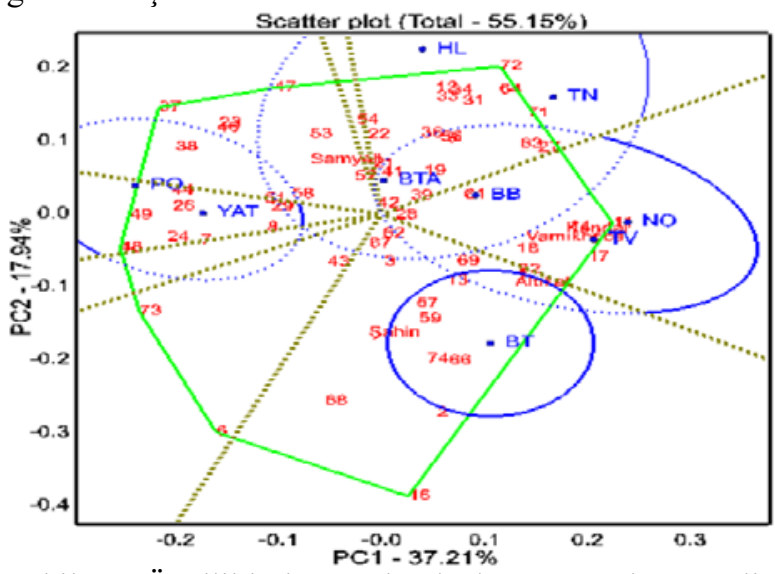

Şekil 1B. Özelliklerin gruplandırılması ve sektör analizi ile genotip özellik ilişkisi

Figure 1B. The genotype trait and the relationship with sector analysis of grouping traits

Özellikler ve genotipler ortalama verilere göre toplam 8 sektöre ayrılmıştır. Özellikler ağırlıklı olarak 4 sektöre dağılırken toplam 5 grupta toplanmıştır. Başaklanma tarihi(BT) yani süresi tek başına 1. Sektörde, ve 1. TV, NO ve BB ise 2. Sektörde ve 2. Grupta, BTA, HL ve TN ise 3. Sektörde ve 3. Grupta, Yatma ve PO ise 6. Sektörde ve 4. Grupta yer almışlardır. Kalan diğer 4 sektörlerde sadece bazı genotipler yer alırken, 59,66 ve 74 gibi bazı genotipler BT ile aynı grupta ve sektörde yer alırken geçci oldukları, özellikle 11, 17, 18 nolu hatlar ile Altıkat, Kendal ve Vamıhkhoca çeşitleri ise $\mathrm{TV}$, BB ve NO oranı ile aynı grup ve sektörde yer alarak bu genotiplerin oldukça verimli ortalama bitki boyuna sahip ve yüksek nişasta değerlerine sahip oldukları, 12, 31, 64,71,72 ve diğer bazı genotipler ise BTA, HL ve TN ile aynı sektör ve grupta yer alarak aslında fiziksel kalite özellikleri bakımından yüksek değerlere sahip oldukları, 24,26, 38 ve 49 ile diğer bazı genotipler Yatma ve PO oranı ile aynı sektörü paylaşmış ve aynı grupta yer almışlardır. Öbür taraftan 6,73 ve 37 nolu hatlar her hangi bir özellik ile aynı grupta yer almayıp bağımsız bir şekilde farklı sektörlerde yer almışlardır. Dolayısıyla bu hatlar ile özelikler ile aynı grubu paylaşmayan diğer bazı hatlar her hangi bir özellik bakımından öne çıkmamışlardır.
Ranking biplot incelenen özelliklere ait verilerin ortalaması bakımından genotiplerin stabilitesi hakkında bilgi vermektedir (Şekil 1C). Yatay ve ok ile gösterilen eğri özelliklerin ortalaması bakımından oluşturulmakta ve özelliklerin ortalamasına göre stabilitesi hakkında bize fikir sunmaktadır. Dikey eğri ise özelliklerin ortalamasını göstermektedir. Dikey eğrinin üzerinde ve yatay eğriye yakın ve uç kısımlarda yer alan genotiplerin(27, 62 ve 71 nolu hatlar gibi) tüm özellikler bakımından oldukça stabil oldukları, yatay eğriden uzakta yer alanlar(17 ve 72 nolu hatlar) oldukça değişken,dikey eğrinin altında yer alan genotipler

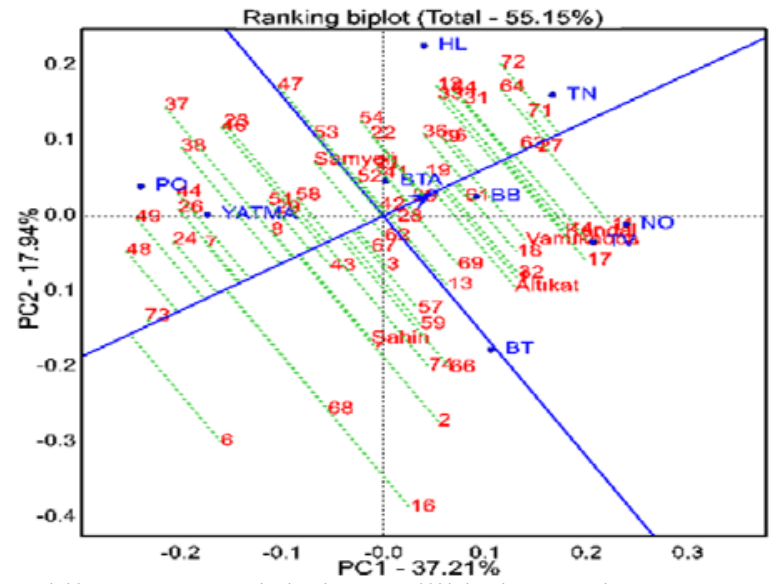

Şekil 1C. Genotiplerin özelliklerin ortalamasını göre stabilitesi

Figure 1C. Stability of genotypes according to the mean of the traits

(6,16 ve73 nolu hatlar) ise tercih edilmeyen ortalamanın altında kalan genotipler olarak tespit edilmiştir. Ayrıca hangi genotipler hangi özellik tarafında yer alıyorsa yukarıda açıklandığı gibi o özelliklerle ilişkilendirilmektedir.

Comparison biplot özelliklerin ortalama verileri üzerinden oluşturulan temsili ideal merkez oluşturmakta genotip veya özellikler bu merkeze göre değerlendirilmektedir (Şekil 1D).

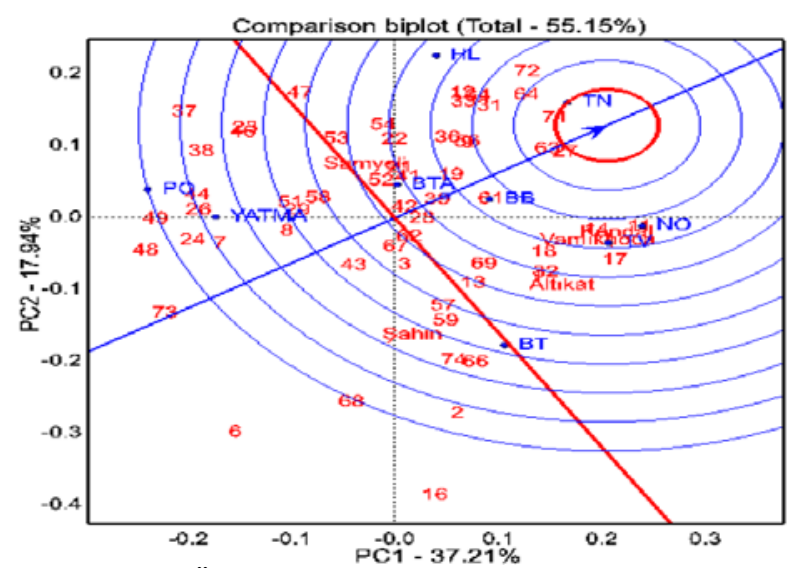

Şekil 1D. Özelliklerin ortalamasına göre en ideal genotiplerin belirlenmesi 
Figure 1D. Determination of the most ideal genotypes according to the average of the trait

Bu modele göre 27, 62 ve 71 nolu hatlar ideal merkeze yakın oldukları ve dolayısıyla tüm özellikler

şeklinde çizilen bölgenin dışında kalan genotipler ise tüm özelliklerin ortalamasına göre tercih edilmeyen düşük değerlere sahip oldukları tespit edilmiştir.GT yani GÖ tekniğinde göründüğü gibi tüm özellikler bakımından hangi genotiplerin seçilmesi konusunda karar vermek bizi yormaktadır. Ancak bu seleksiyon GYT yani GVÖ tekniğinde gayet rahat olmaktadır (Karahan ve Akgün, 2020). GT biplot tekniği çok sayıda genotiple yapılan çalışmalarda seleksiyonda görsel açıdan kısmi olarak bize kolaylık sağlamaktadır. Benzer yorumlar birçok araștırıcı tarafından farklı araştırma sonuçlarında da bildirilmiştir (Kılıç ve ark., 2018;Kendal ve ark., 2019; Malik ve ark., 2014; Solonechnyi ve ark., 2018).

\subsection{GYT(genotype*trait) yani $\quad$ GVÖ(genotip, verim*özellik) Biplot Tekniğ $i$}

$\mathrm{Bu}$ teknikle Tablo 4'teki veriler kullanılarak dört ayrı şekil oluşturulmuştur. Şekil 2A: araştırmada incelenen özellik-verim kombinasyon verileri kullanılarak özellik-verim kombinasyonları ile genotipler arasındaki ilişkiyi, Şekil 1B: özellik-verim kombinasyonlarının gruplandırılması ve genotipler ile bu kombinasyonların sektörlere göre ilişkisi, Şekil 1C: özellik-verim kombinasyonlarına ait verilerin ortalaması bakımından genotiplerin stabilitesi, Şekil 1D: özellikverim kombinasyonların ortalama verileri üzerinden oluşturulan temsili ideal merkeze göre genotiplerin değerlendirilmesi şeklinde açıklanmaktadır (Kendal, 2019; Yan ve ark., 2019; Karahan ve Akgün, 2020). GVÖ biplot tekniğinde iki boyutlu PCA skoru toplam varyasyonun, \% 93.17'ini oluştururken, PCI \% 85.65'lik ve PC2 \% 7.53' lük bir paya sahip olmuştur. GVÖ biplot tekniği GÖ tekniğine göre daha yüksek bir varyasyonu temsil ettiği tespit edilmiştir.Çizelge 3' teki veriler kullanılarak her bir özellik ile tane verimi arasında kombinasyonlar oluşturulmuş ve Çizelge 4 elde edilmiştir. GYT yani GVÖ tekniği Çizelge 4 verileri kullanılarak oluşturulmuştur. Ancak bu tabloda kombinasyonlar oluşturulurken, tane verimi, verimi olumsuz etkileyen özelliklere bölünerek veriler elde edilmiştir (TV/YATMA, TV/BB, TV/BT). Çünkü Diyarbakır şartlarında, arpa yetiştiriciliğinde geçcilik, yüksek boyluluk dolayısıyla yüksek yatma oranı verimi düşüren özelliklerdir. Aksine diğer özelliklerin verime olumlu etki yapacağı için çarpılarak kombinasyonlar oluşturulmuştur(TV*BTA, TV*HL, TV*NO, TV*PO, TV*TR). Çünkü GVÖ tekniğinde her zaman kombinasyonda yüksek değerler tercih edilmektedir. Ayrıca GVÖ verilerini grafiksel olarak gösteren ve farklı açıdan grafiklerin yorumlanmasına imkan veren bakımından ideal değerlere sahip oldukları, dikey eğri ile ideal merkez arasındaki bölgede kalanlar tercih edilebilir genotipler, dikey eğrinin altında ve daire

bir tekniktir (Şekil 2A-B-C-D). Dolayısıyla verim veya herhangi bir özellik tek başına kullanılmayıp her biri etki derecesine göre verim ile kombinasyona girerek gerçek GVÖ verilerin elde edilmesine ve grafiklerin oluşmasına katkı sunmaktadır. Kısacası tüm verim öğeleri verimle kombinasyona girerek gerçek verimi verdiklerinden dolayı çoğu birbiri ile pozitif bir korelasyon eğilimine girmektedir. $\mathrm{Bu}$ durum GVÖ(GYT) tekniğini GÖ(GT) tekniğinden ayıran en önemli özelliği olup aşağıdaki şekillerde etkisini görmek mümkündür(Yan ve Frégeau-Reid, 2018). Bu açıklama doğrultusunda Şekil 2A, araştırmada incelenen özellik-verim kombinasyon verileri kullanılarak özellikverim kombinasyonları ile genotipler arasındaki ilişkiyi göstermektedir. $\mathrm{Bu}$ şekil grafiksel olarak GT biplot tekniği bölümünde(Şekil 1A) yeterince açıklanmıştır.

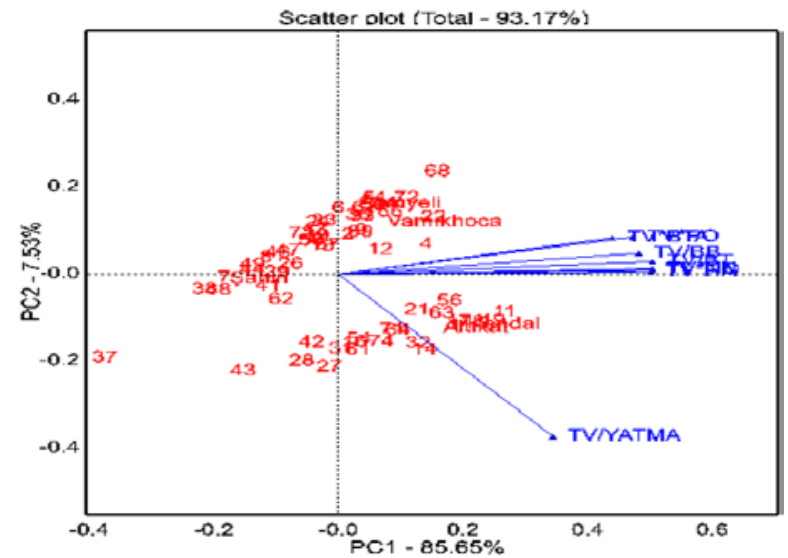

Şekil 2A. Verim-özellik kombinasyonları ile genotipler arasındaki ilişkiler

Figure 2A. Relationships between genotypes by yieldtrait combinations

$\mathrm{Bu}$ açıklamalar doğrultusunda (Şekil 2A) TV ile kombinasyona giren özelliklerin çoğu yüksek ve pozitif bir korelasyon içerisinde olduğu görülmektedir. Sadece TV/Yatma kombinasyonu ile diğer kombinasyonlar arasında zayıf bir ilişki olduğu tespit edilmiştir. Elde edilen kombinasyonların sonuçlarına göre özellikle $11,17,18,21,56,63$ nolu hatlar ile Altıkat ve Kendal çeşitlerinin iyi sonuçlara sahip oldukları görülmektedir. $\mathrm{Bu}$ genotiplerin durumunu özellik-verim kombinasyonlarının gruplandırılması ve genotipler ile bu kombinasyonların sektörlere göre ilişkisini gösteren Şekil 1B' de daha net görmek mümkündür (Yan ve ark., 2019). 


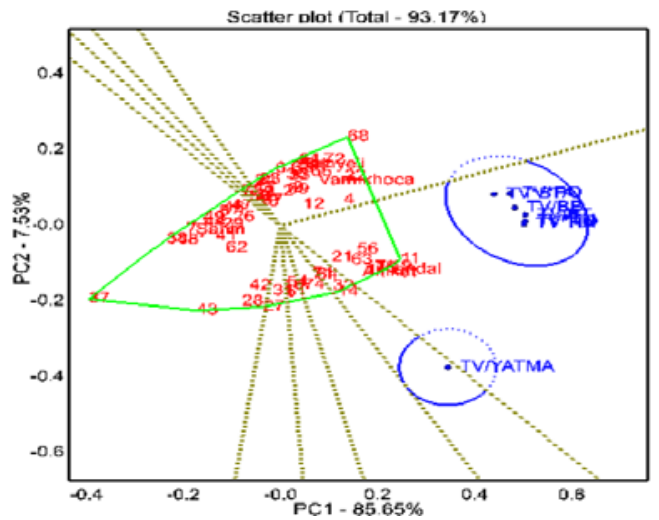

Şekil 2B. Kombinasyonların gruplandırılması ile genotiplerin sektörlere göre ilişkisi

Figure 2B. Relationship between genotypes and grouping combinations by sectors analysis

Çizelge 4. Arpa genotiplerin verim × özellik (GVÖ) kombinasyonu verileri

Table 4 . The genotypes yield ${ }^{\times}$trait (GYT) combination data

\begin{tabular}{|c|c|c|c|c|c|c|c|c|}
\hline No: & $\begin{array}{l}\text { TV/BS } \\
G Y / H T\end{array}$ & $\begin{array}{l}\mathrm{TV} / \mathrm{BB} \\
G Y / P H\end{array}$ & $\begin{array}{l}\text { TV*BTA } \\
G Y / T G W\end{array}$ & $\begin{array}{l}\text { TV*HA } \\
G Y / H W\end{array}$ & $\begin{array}{l}\mathrm{TV}^{*} \mathrm{PO} \\
G Y / P C\end{array}$ & $\begin{array}{c}\mathrm{TV} * \mathrm{NO} \\
G Y / S C \\
\end{array}$ & $\begin{array}{l}\mathrm{TV} * \mathrm{TN} \\
G Y / G M\end{array}$ & $\begin{array}{l}\text { TV/YAT } \\
\text { GY/LOD }\end{array}$ \\
\hline 01 & 6.5 & 6.8 & 33210 & 51256 & 10411 & 52560 & 6051 & 749 \\
\hline 02 & 5.3 & 5.7 & 18226 & 40203 & 9286 & 44333 & 5104 & 126 \\
\hline 03 & 4.6 & 5.1 & 27183 & 37172 & 8370 & 37789 & 4363 & 108 \\
\hline 04 & 6.2 & 6.3 & 32650 & 49903 & 9685 & 51534 & 6028 & 364 \\
\hline 06 & 5.0 & 6.1 & 25270 & 36064 & 9169 & 39278 & 4573 & 73 \\
\hline 07 & 3.3 & 3.5 & 19821 & 26628 & 6691 & 25875 & 3069 & 64 \\
\hline 08 & 3.8 & 4.3 & 23311 & 30925 & 7480 & 30362 & 3619 & 90 \\
\hline 09 & 5.2 & 5.6 & 30947 & 42245 & 8861 & 41319 & 4923 & 198 \\
\hline 11 & 6.9 & 7.5 & 40682 & 56277 & 10588 & 57199 & 6691 & 808 \\
\hline 12 & 5.5 & 5.4 & 33483 & 44433 & 9004 & 42026 & 4976 & 304 \\
\hline 13 & 4.7 & 5.0 & 22412 & 38684 & 7889 & 39151 & 4488 & 111 \\
\hline 14 & 6.2 & 6.2 & 26730 & 48296 & 9256 & 49962 & 5894 & 712 \\
\hline 16 & 4.8 & 5.8 & 26336 & 36334 & 8478 & 40741 & 4607 & 584 \\
\hline 17 & 6.4 & 6.0 & 39252 & 50757 & 10087 & 52655 & 6111 & 747 \\
\hline 18 & 6.6 & 7.6 & 31979 & 50611 & 10649 & 52999 & 6297 & 760 \\
\hline 19 & 7.2 & 8.3 & 25867 & 53814 & 11891 & 53611 & 6519 & 787 \\
\hline 21 & 5.6 & 6.4 & 33610 & 46019 & 10299 & 43808 & 5168 & 639 \\
\hline 22 & 6.1 & 6.8 & 35271 & 47266 & 10984 & 46216 & 5512 & 337 \\
\hline 23 & 4.6 & 5.1 & 26898 & 35114 & 9381 & 34273 & 4148 & 101 \\
\hline 24 & 4.6 & 4.8 & 27531 & 33842 & 9338 & 34166 & 3977 & 101 \\
\hline 26 & 4.4 & 4.8 & 19473 & 31056 & 8534 & 31604 & 3750 & 156 \\
\hline 27 & 4.8 & 5.4 & 17719 & 38418 & 7400 & 38785 & 4600 & 547 \\
\hline 28 & 4.3 & 4.7 & 18878 & 34790 & 7537 & 33977 & 4090 & 498 \\
\hline 29 & 3.8 & 4.4 & 20366 & 32177 & 8009 & 30689 & 3578 & 149 \\
\hline 31 & 4.8 & 5.4 & 21735 & 39574 & 8243 & 38249 & 4527 & 545 \\
\hline 32 & 5.9 & 6.7 & 27729 & 47459 & 8943 & 48331 & 5567 & 687 \\
\hline 33 & 5.5 & 5.7 & 26282 & 43992 & 8315 & 42822 & 4972 & 87 \\
\hline 34 & 5.8 & 6.0 & 26916 & 46795 & 9013 & 45041 & 5339 & 92 \\
\hline 36 & 5.3 & 5.6 & 24810 & 43505 & 8905 & 42055 & 4897 & 85 \\
\hline 37 & 1.7 & 1.8 & 7354 & 13537 & 3398 & 13073 & 1545 & 27 \\
\hline 38 & 3.1 & 2.9 & 18998 & 22817 & 6026 & 22942 & 2756 & 49 \\
\hline 39 & 4.5 & 4.3 & 29114 & 36937 & 8079 & 36607 & 4247 & 105 \\
\hline 41 & 4.3 & 3.9 & 15044 & 32016 & 7109 & 32525 & 3957 & 119 \\
\hline 42 & 4.2 & 4.6 & 24953 & 34885 & 7954 & 34031 & 4000 & 493 \\
\hline 43 & 3.5 & 3.5 & 15549 & 27975 & 6624 & 27963 & 3270 & 408 \\
\hline
\end{tabular}




\begin{tabular}{|c|c|c|c|c|c|c|c|c|}
\hline 44 & 3.7 & 5.0 & 15805 & 28394 & 7056 & 27685 & 3321 & 68 \\
\hline 46 & 4.1 & 4.5 & 19919 & 32331 & 7679 & 30664 & 3768 & 66 \\
\hline 47 & 4.3 & 4.7 & 19446 & 34872 & 7812 & 32432 & 3904 & 68 \\
\hline 48 & 3.1 & 3.4 & 13937 & 26099 & 7145 & 24295 & 2894 & 73 \\
\hline 49 & 3.8 & 4.0 & 18109 & 28343 & 7527 & 28035 & 3382 & 60 \\
\hline 51 & 5.6 & 6.4 & 23454 & 43311 & 9983 & 42123 & 5038 & 78 \\
\hline 52 & 5.6 & 6.0 & 27132 & 43477 & 9282 & 42912 & 5029 & 103 \\
\hline 53 & 4.7 & 4.5 & 21892 & 37186 & 8433 & 35649 & 4336 & 88 \\
\hline 54 & 5.0 & 5.8 & 23136 & 42209 & 8965 & 38587 & 4581 & 565 \\
\hline 56 & 6.1 & 6.4 & 37896 & 48901 & 11012 & 47721 & 5661 & 690 \\
\hline 57 & 4.7 & 5.4 & 25922 & 36933 & 7689 & 38591 & 4496 & 139 \\
\hline 58 & 4.6 & 5.0 & 23541 & 34330 & 8283 & 34785 & 4206 & 102 \\
\hline 59 & 5.4 & 5.9 & 30590 & 41594 & 8791 & 44060 & 5141 & 106 \\
\hline 61 & 5.1 & 5.0 & 21927 & 41151 & 9105 & 41027 & 4832 & 589 \\
\hline 62 & 4.0 & 4.2 & 19186 & 32867 & 7659 & 32721 & 3818 & 235 \\
\hline 63 & 5.9 & 6.4 & 33227 & 49863 & 10858 & 48478 & 5722 & 689 \\
\hline 64 & 5.4 & 5.8 & 28311 & 46553 & 9614 & 43856 & 5198 & 626 \\
\hline 66 & 5.6 & 6.7 & 28171 & 41191 & 9270 & 46061 & 5410 & 165 \\
\hline 67 & 5.2 & 6.4 & 26894 & 40750 & 9015 & 41402 & 4912 & 100 \\
\hline 68 & 6.1 & 7.3 & 34093 & 46128 & 11471 & 48834 & 5647 & 179 \\
\hline 69 & 5.1 & 5.9 & 24024 & 42329 & 8871 & 42566 & 4999 & 152 \\
\hline 71 & 5.4 & 5.5 & 31537 & 44881 & 9140 & 43636 & 5143 & 619 \\
\hline 72 & 5.7 & 5.7 & 33263 & 48465 & 10066 & 46018 & 5544 & 165 \\
\hline 73 & 4.4 & 5.3 & 17595 & 32499 & 9268 & 33592 & 3998 & 62 \\
\hline 74 & 5.4 & 5.8 & 24747 & 40968 & 9452 & 43722 & 5024 & 627 \\
\hline Kendal & 6.6 & 7.5 & 31661 & 54085 & 10812 & 54626 & 6399 & 774 \\
\hline Altıkat & 6.3 & 7.1 & 31981 & 50492 & 10232 & 51605 & 6055 & 741 \\
\hline Samyeli & 5.4 & 5.8 & 28385 & 41300 & 9901 & 40980 & 4890 & 120 \\
\hline Şahin 91 & 3.4 & 3.5 & 19044 & 28846 & 6702 & 29090 & 3419 & 70 \\
\hline Vamıkhoca 98 & 5.8 & 5.7 & 33484 & 45895 & 9179 & 47107 & 5543 & 224 \\
\hline Ortalama(Mean) & 5.0 & 5.5 & 25598 & 39816 & 8802 & 39868 & 4700 & 306 \\
\hline $\begin{array}{l}\text { Standart Sapma } \\
\text { Standart Devision }\end{array}$ & 1.1 & 1.2 & 6659 & 8440 & 1442 & 8772 & 1017 & 266 \\
\hline
\end{tabular}

TV: Tane verimi(grain yield), BS: başaklanma süresi(heading time), BB:bitki boyu(plant height), HL: hektolitre ağırlığı(hectoliter weight), BTA: bin tane ağıllığı(thousant grain weight), PO: protein oranı(protein content), NO: nişasta oranı (starch content), TN: tane nem oranı(grain moister).

Burada kombinasyonlar ile aynı sektörde yer alan genotipler genelde kombinasyonlar sonucunda en iyi sonuçlara sahip seleksiyonda seçilmesi gereken genotipler, kombinasyonların aksine diğer sektörlerde yer alan genotipler ise istediğimiz özelliklere sahip olmayan ve seleksiyonda aslinda elenmesi gereken genotiplerdir. Bu nedenle bu grafikler bize görsel olarak çok kolay ve etkin bir seleksiyon yapmamıza olanak sağlamaktadır. Benzer şekilde özellik-verim kombinasyonlarına ait verilerin ortalaması bakımından genotiplerin stabilitesini Şekil 1C' de görmek mümkündür(Karahan ve Akgün, 2020).

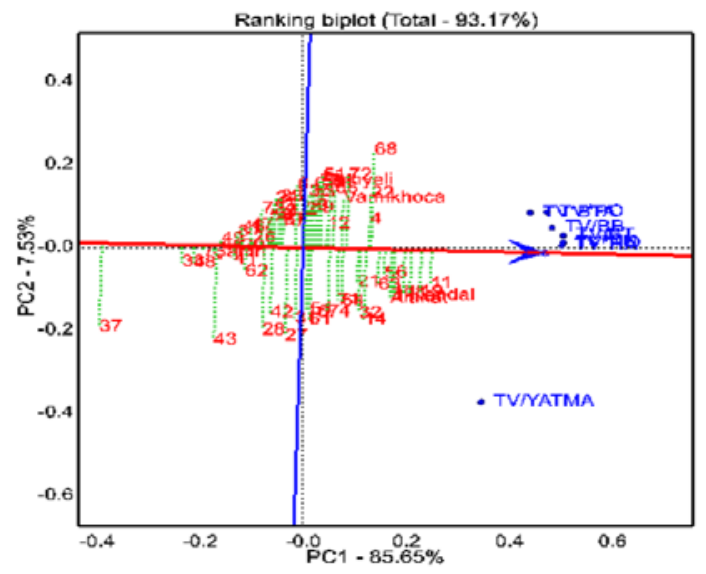

Şekil 2C. Kombinasyonların ortalama verilerine göre genotiplerin stabilitesi

Figure 2C. Stability of genotypes according to the average data of combinations 
$\mathrm{Bu}$ şekilde görüldüğü gibi özellikle yukarıdaki şekillerde(2A-2B) iyi sonuçlara sahip olduğu belirtilen $11,17,18,21,56,63$ nolu hatlar ile Altıkat ve Kendal genotiplerin stabilite eğrisine(yatay eğri) yakın diğer genotiplere göre oldukça ilerde aynı zamanda ortalama eğrinin(dikey) üzerinde yer aldıkları için stabil olduklarını da söylemek mümkündür. Bununla birlikte yine diğer bazı genotiplerin (örn:4 nolu genotip) stabil eğrisine yakın ve ortalamanın hemen yer aldıkları, 3 ve 4 nolu hatlar gibi bazı genotipler de hem stabilite eğrisinden uzak hem de ortalama eğrinin altında bazı sonuçlara sahip oldukları tespit edilmiştir. Bir başka açıdan özellik-verim kombinasyonların ortalama verileri üzerinden oluşturulan temsili ideal merkeze göre genotiplerin değerlendirilmesini Şekil 1D'ye göre de yapmak mümkündür(Kendal, 2019). Burada kombinasyonların ortalamasından oluşturulan temsili ideal merkeze göre genotipleri değerlendirdiğimizde yukarıda öne çıkan genotiplerin burada da temsili merkeze(en içteki çember) en yakın genotipler oldukları dolayısıyla seleksiyonda ilk bu genotiplerin seçilmesi gerektiği, diğer genotiplerden sadece bazıları en dıştaki çemberlerde yer aldıkları dolayısıyla ikinci dereceden tercih edilebileceği, ortalama dikey eğri ile çemberler arasındaki bölgede yer alan genotipler yine seleksiyonda son olarak seçilebilecek ancak ortalama eğrinin altında yer alan genotiplerin seleksiyonda seçilemeyeceğini bize göstermektedir. Bu şekilde yatma oranının merkezi çemberden oldukça uzak olduğunu, diğer kombinasyonlardan oldukça uzakta yer aldığını ve seleksiyonda etkisinin oldukça az olacağını söylemek mümkündür. GÖ tekniğinde 37 nolu hat $\mathrm{HL}$ ile $\mathrm{PO}$ arasında yer alırken, GVÖ tekniğinde ise düşük verim,
Şekil 2D. Kombinasyonların ortalamasından elde edilen ideal merkeze göre genotiplerin değerlendirilmesi Figure 2D. Evaluation of genotypes according to the ideal center obtained from the average of the combination

yüksek yatma ve diğer bazı kalite kriterlerine ait verilerin düşüklügünnden dolayı verim ile girdikleri kombinasyonların etki değerleri de düşmüş dolayısıyla tüm kombinasyonların tersi istikametinde yer almış ve seleksiyonda elenmesi gereken hat konumuna düşmüştür. Oysa sadece GÖ sonuçlarına bakıp yapılacak bir seleksiyonda belki de yüksek $P O$ ve HL değerinden dolayı seçilme olanağına sahipti ancak GVÖ tekniği ile bu zayıf ihtimal ortadan kaldırılmış bu durum diğer bazı hatlar için de geçerlidir. Yapılan ıslah çalışmalarında çoğu zaman tek veya birkaç özelliğin sonuçları bağımsız değerlendirilerek seleksiyon yapılmaktadır. $\mathrm{Bu}$ nedenle 1slahta yeterince başarı sağlanamamaktadır. Ancak yeni bir seleksiyon yaklaşımını öngören GVÖ biplot tekniği ile çoklu özelliklere dayalı ve kombinasyonların etkisi ile genotiplerin zayıf ve güçlü yönlerine göre seleksiyonun yapılması bu eksikliği giderecek ve seleksiyon başarısını dolayısıyla ıslah başarısını artıracaktır. $\mathrm{Bu}$ nedenle, verim-özellik kombinasyonlarının etkisi, üstün çeşitlerin seçilmesindeki bireysel özelliklerin etkisinden daha anlamlıdır(Yan ve ark., 2019). Kombinasyonların verileri standart hale getirildikten sonra üstünlük indeksi verileri elde edilmektedir(Çizelge 5). Bitki 1slahı çalışmalarında genotipler GVÖ biplot tekniği ile oluşturulan grafiklere bakılarak görsel ve üstünlük indeksi değerlerine bakılarak isabetli bir seleksiyona yapılmakta ve en uygun çeşit adayları belirlenebilmektedir.

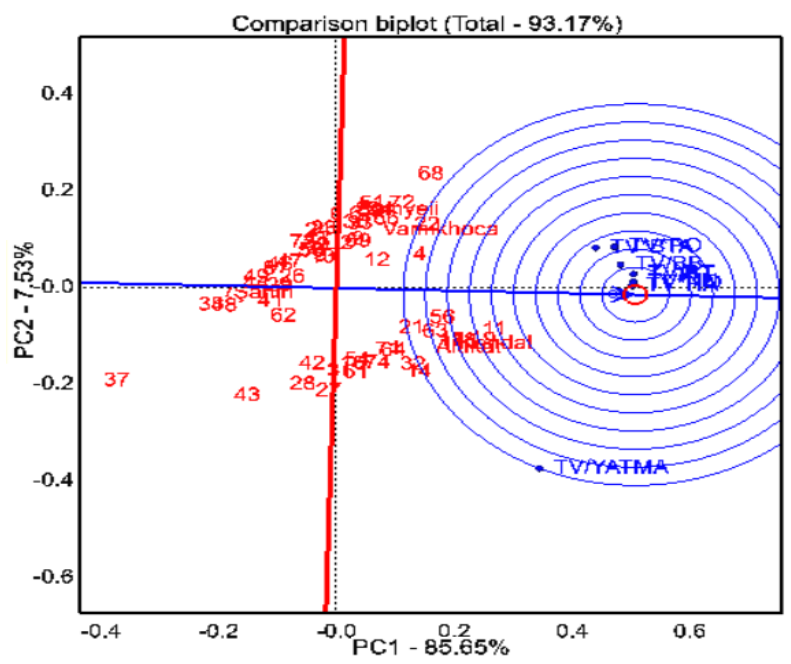

Çizelge 5. Verimº̈zellik kombinasyonu verilerine göre genotiplerin standardizasyonu ve genotiplerin üstünlük endeksi

Table 5. Standardization of genotypes and superiority index of genotypes according to yield*trait combination data 


\begin{tabular}{|c|c|c|c|c|c|c|c|c|c|}
\hline No: & $\begin{array}{l}\text { TV/BS } \\
G Y / H T\end{array}$ & $\begin{array}{l}\text { TV/BB } \\
G Y / P H\end{array}$ & $\begin{array}{l}\Gamma \mathrm{V}^{*} \mathrm{BTA} \\
\xi Y^{*} T G W\end{array}$ & $\begin{array}{l}\mathrm{TV} * \mathrm{HA} \\
G Y^{*} H W\end{array}$ & $\begin{array}{l}\mathrm{TV}^{*} \mathrm{PO} \\
G Y^{*} P C\end{array}$ & $\begin{array}{l}\mathrm{TV}^{*} \mathrm{NO} \\
G Y^{*} S C\end{array}$ & $\begin{array}{l}\mathrm{TV}^{*} \mathrm{TN} \\
G Y^{*} G M\end{array}$ & $\begin{array}{l}\text { TV/YAT } \\
\text { GY/LOD }\end{array}$ & $\begin{array}{c}\text { Ort Mean } \\
\text { (Üstünlük } \\
\text { Endeksi/ } \\
\text { Sup. Index) }\end{array}$ \\
\hline 01 & 1.30 & 1.23 & 1.30 & 1.29 & 1.18 & 1.32 & 1.29 & 2.81 & 1.46 \\
\hline 02 & 1.06 & 1.04 & 0.71 & 1.01 & 1.06 & 1.11 & 1.09 & 0.47 & 0.94 \\
\hline 03 & 0.92 & 0.93 & 1.06 & 0.93 & 0.95 & 0.95 & 0.93 & 0.41 & 0.88 \\
\hline 04 & 1.24 & 1.15 & 1.28 & 1.25 & 1.10 & 1.29 & 1.28 & 1.37 & 1.24 \\
\hline 06 & 1.00 & 1.11 & 0.99 & 0.91 & 1.04 & 0.99 & 0.97 & 0.27 & 0.91 \\
\hline 07 & 0.66 & 0.63 & 0.77 & 0.67 & 0.76 & 0.65 & 0.65 & 0.24 & 0.63 \\
\hline 08 & 0.77 & 0.77 & 0.91 & 0.78 & 0.85 & 0.76 & 0.77 & 0.34 & 0.74 \\
\hline 09 & 1.04 & 1.03 & 1.21 & 1.06 & 1.01 & 1.04 & 1.05 & 0.74 & 1.02 \\
\hline 11 & 1.37 & 1.37 & 1.59 & 1.41 & 1.20 & 1.43 & 1.42 & 3.04 & 1.61 \\
\hline 12 & 1.09 & 0.98 & 1.31 & 1.12 & 1.02 & 1.05 & 1.06 & 1.14 & 1.10 \\
\hline 13 & 0.94 & 0.91 & 0.88 & 0.97 & 0.90 & 0.98 & 0.95 & 0.42 & 0.87 \\
\hline 14 & 1.24 & 1.12 & 1.04 & 1.21 & 1.05 & 1.25 & 1.25 & 2.67 & 1.36 \\
\hline 16 & 0.96 & 1.06 & 1.03 & 0.91 & 0.96 & 1.02 & 0.98 & 2.20 & 1.14 \\
\hline 17 & 1.27 & 1.08 & 1.53 & 1.27 & 1.15 & 1.32 & 1.30 & 2.81 & 1.47 \\
\hline 18 & 1.33 & 1.38 & 1.25 & 1.27 & 1.21 & 1.33 & 1.34 & 2.86 & 1.50 \\
\hline 19 & 1.44 & 1.50 & 1.01 & 1.35 & 1.35 & 1.34 & 1.39 & 2.96 & 1.54 \\
\hline 21 & 1.13 & 1.16 & 1.31 & 1.16 & 1.17 & 1.10 & 1.10 & 2.40 & 1.32 \\
\hline 22 & 1.22 & 1.25 & 1.38 & 1.19 & 1.25 & 1.16 & 1.17 & 1.27 & 1.23 \\
\hline $\begin{array}{l}23 \\
24\end{array}$ & $\begin{array}{l}0.92 \\
0.91\end{array}$ & $\begin{array}{l}0.92 \\
0.87\end{array}$ & $\begin{array}{l}1.05 \\
1.08\end{array}$ & $\begin{array}{l}0.88 \\
0.85\end{array}$ & $\begin{array}{l}1.07 \\
1.06\end{array}$ & $\begin{array}{l}0.86 \\
0.86\end{array}$ & $\begin{array}{l}0.88 \\
0.85\end{array}$ & $\begin{array}{l}0.38 \\
0.38\end{array}$ & $\begin{array}{l}0.87 \\
0.86\end{array}$ \\
\hline 26 & 0.87 & 0.88 & 0.76 & 0.78 & 0.97 & 0.79 & 0.80 & 0.59 & 0.80 \\
\hline 27 & 0.96 & 0.98 & 0.69 & 0.96 & 0.84 & 0.97 & 0.98 & 2.06 & 1.06 \\
\hline 28 & 0.86 & 0.85 & 0.74 & 0.87 & 0.86 & 0.85 & 0.87 & 1.87 & 0.97 \\
\hline 29 & 0.77 & 0.80 & 0.80 & 0.81 & 0.91 & 0.77 & 0.76 & 0.56 & 0.77 \\
\hline 31 & 0.97 & 0.97 & 0.85 & 0.99 & 0.94 & 0.96 & 0.96 & 2.05 & 1.09 \\
\hline 32 & 1.19 & 1.23 & 1.08 & 1.19 & 1.02 & 1.21 & 1.18 & 2.58 & 1.34 \\
\hline 33 & 1.11 & 1.03 & 1.03 & 1.10 & 0.94 & 1.07 & 1.06 & 0.33 & 0.96 \\
\hline 34 & 1.15 & 1.09 & 1.05 & 1.18 & 1.02 & 1.13 & 1.14 & 0.35 & 1.01 \\
\hline 36 & 1.05 & 1.02 & 0.97 & 1.09 & 1.01 & 1.06 & 1.04 & 0.32 & 0.94 \\
\hline 37 & 0.35 & 0.32 & 0.29 & 0.34 & 0.39 & 0.33 & 0.33 & 0.10 & 0.31 \\
\hline 38 & 0.62 & 0.53 & 0.74 & 0.57 & 0.68 & 0.58 & 0.59 & 0.18 & 0.56 \\
\hline 39 & 0.90 & 0.78 & 1.14 & 0.93 & 0.92 & 0.92 & 0.90 & 0.39 & 0.86 \\
\hline 41 & 0.85 & 0.71 & 0.59 & 0.80 & 0.81 & 0.82 & 0.84 & 0.45 & 0.73 \\
\hline 42 & 0.85 & 0.84 & 0.97 & 0.88 & 0.90 & 0.85 & 0.85 & 1.85 & 1.00 \\
\hline 43 & 0.71 & 0.64 & 0.61 & 0.70 & 0.75 & 0.70 & 0.70 & 1.53 & 0.79 \\
\hline 44 & 0.73 & 0.91 & 0.62 & 0.71 & 0.80 & 0.69 & 0.71 & 0.26 & 0.68 \\
\hline 46 & 0.82 & 0.82 & 0.78 & 0.81 & 0.87 & 0.77 & 0.80 & 0.25 & 0.74 \\
\hline 47 & 0.85 & 0.85 & 0.76 & 0.88 & 0.89 & 0.81 & 0.83 & 0.26 & 0.77 \\
\hline 48 & 0.62 & 0.62 & 0.54 & 0.66 & 0.81 & 0.61 & 0.62 & 0.28 & 0.59 \\
\hline 49 & 0.76 & 0.72 & 0.71 & 0.71 & 0.86 & 0.70 & 0.72 & 0.23 & 0.68 \\
\hline 51 & 1.11 & 1.15 & 0.92 & 1.09 & 1.13 & 1.06 & 1.07 & 0.29 & 0.98 \\
\hline 52 & 1.12 & 1.10 & 1.06 & 1.09 & 1.05 & 1.08 & 1.07 & 0.39 & 0.99 \\
\hline 53 & 0.94 & 0.82 & 0.86 & 0.93 & 0.96 & 0.89 & 0.92 & 0.33 & 0.83 \\
\hline 54 & 1.00 & 1.05 & 0.90 & 1.06 & 1.02 & 0.97 & 0.97 & 2.12 & 1.14 \\
\hline 56 & 1.22 & 1.16 & 1.48 & 1.23 & 1.25 & 1.20 & 1.20 & 2.59 & 1.42 \\
\hline 57 & 0.95 & 0.98 & 1.01 & 0.93 & 0.87 & 0.97 & 0.96 & 0.52 & 0.90 \\
\hline 58 & 0.92 & 0.91 & 0.92 & 0.86 & 0.94 & 0.87 & 0.89 & 0.39 & 0.84 \\
\hline 59 & 1.08 & 1.07 & 1.20 & 1.04 & 1.00 & 1.11 & 1.09 & 0.40 & 1.00 \\
\hline 61 & 1.02 & 0.91 & 0.86 & 1.03 & 1.03 & 1.03 & 1.03 & 2.21 & 1.14 \\
\hline 62 & 0.81 & 0.76 & 0.75 & 0.83 & 0.87 & 0.82 & 0.81 & 0.89 & 0.82 \\
\hline
\end{tabular}




\begin{tabular}{cccccccccc}
\hline 63 & 1.18 & 1.16 & 1.30 & 1.25 & 1.23 & 1.22 & 1.22 & 2.59 & 1.39 \\
64 & 1.09 & 1.05 & 1.11 & 1.17 & 1.09 & 1.10 & 1.11 & 2.35 & 1.26 \\
66 & 1.13 & 1.22 & 1.10 & 1.03 & 1.05 & 1.16 & 1.15 & 0.62 & 1.06 \\
67 & 1.03 & 1.17 & 1.05 & 1.02 & 1.02 & 1.04 & 1.05 & 0.37 & 0.97 \\
68 & 1.21 & 1.33 & 1.33 & 1.16 & 1.30 & 1.23 & 1.20 & 0.67 & 1.18 \\
69 & 1.02 & 1.08 & 0.94 & 1.06 & 1.01 & 1.07 & 1.06 & 0.57 & 0.98 \\
71 & 1.08 & 1.00 & 1.23 & 1.13 & 1.04 & 1.09 & 1.09 & 2.33 & 1.25 \\
72 & 1.15 & 1.04 & 1.30 & 1.22 & 1.14 & 1.15 & 1.18 & 0.62 & 1.10 \\
73 & 0.88 & 0.96 & 0.69 & 0.82 & 1.05 & 0.84 & 0.85 & 0.23 & 0.79 \\
74 & 1.07 & 1.06 & 0.97 & 1.03 & 1.07 & 1.10 & 1.07 & 2.36 & 1.22 \\
\hline Kendal & 1.32 & 1.36 & 1.24 & 1.36 & 1.23 & 1.37 & 1.36 & 2.91 & 1.52 \\
Alt1kat & 1.26 & 1.28 & 1.25 & 1.27 & 1.16 & 1.29 & 1.29 & 2.79 & 1.45 \\
Samyeli & 1.08 & 1.06 & 1.11 & 1.04 & 1.12 & 1.03 & 1.04 & 0.45 & 0.99 \\
Şahin 91 & 0.68 & 0.64 & 0.74 & 0.72 & 0.76 & 0.73 & 0.73 & 0.26 & 0.66 \\
Vamıkhoca 98 & 1.15 & 1.03 & 1.31 & 1.15 & 1.04 & 1.18 & 1.18 & 0.84 & 1.11 \\
\hline Ortalama(Mean) & 1.00 & 0.99 & 1.00 & 1.00 & 1.00 & 1.00 & 1.00 & 1.17 & 1.02 \\
Standart Sapma & 0.20 & 0.22 & 0.26 & 0.21 & 0.16 & 0.22 & 0.22 & 1.00 & 0.28 \\
Standart Devision & & & & & & & \\
\hline
\end{tabular}

TV: Tane verimi(grain yield), BS: başaklanma süresi(heading time), BB: bitki boyu(plant height), HL: hektolitre ağırlı̆̆1(hectoliter weight), BTA: bin tane ağırlı̆̆ı(thousand grain weight), PO: protein oranı(protein content), NO: nişasta oranı (starch content), TN: tane nem oranı(grain moister),

\section{Sonuç}

Yazlık arpa 1slah çalışmaları kapsamında yürütülen bu çalışmada en uygun arpa hatlarını belirlemek amacıyla birçok islahçı tarafindan ıslah çalışmalarında kullanılan GÖ(GT) biplot tekniğinin de artık yetersiz olduğu düşünülerek yerine GVÖ (GYT) biplot tekniği kullanılmıştır. $\mathrm{Bu}$ teknik temelde verim-özellik kombinasyonları ve üstünlük indeksi verilerine dayanmaktadır. Kombinasyonların verilerine göre genotiplerin güçlü ve zayıf yönleri belirlenmekte ve grafiksel olarak görsel açıdan iyi bir değerlendirme fırsatını sunmaktadır. Ayrıca üstünlük indeksi verileri sonuçlarına en üstün genotipler belirlenmekte ve etkili bir seleksiyon yapılmaktadır. Hem GVÖ grafiklerine bakılarak görsel olarak hem de üstünlük indeksi değerlerine bakarak üstün indeks $(+110)$ değerlerine sahip başta $1,4,11,17,18,19,21,56$ ve 63 nolu hatlar

\section{Kaynaklar}

Kabak, D., \& Akçura, M. 2017. Bingöl İlinden Toplanan Yerel Çavdarlarda Tane Verimi ve Bazı Özellikler Arasındaki İlişkilerin Biplot Analizi ile İncelenmesi. Türk Tarım ve Doğa Bilimleri Dergisi, 4(2), 227-235.

Karahan, $\mathrm{T}$ ve Akgün, I.2020. Selection of Barley (Hordeum vulgare) Genotypes by GYT (Genotype $\times$ Yield $\times$ Trait) Biplot Technique and its Comparison with GT (Genotype $\times$ Trait). Applied Ecology and Environmental Research, 18(1), 1347-1359. olmak üzere toplam 20 adet hat tespit edilerek bir ileri generasyona aktarılmıştır. Augmented deneme deseni ile çok sayıda genotip ile yapılan bu çalışmada GVÖ biplot tekniği kullanılarak seleksiyon yapılmış ve bu tekniğin ıslah çalışmalarında etkin bir şekilde kullanılabileceği tespit edilmiştir. Ayrıca bu tekniğin diğer bitkilerde ve çok özellikle yürütülen çalışmaların sonuçlarının değerlendirilmesinde örnek teşkil edeceği ve araştırıcılara kolaylık sağlayacağı ortaya konulmuştur.

\section{Teşekkür}

$\mathrm{Bu}$ çalışmanın yürütülmesinde desteklerini esirgemeyen GAP Uluslararası Tarımsal Araştırma ve Eğitim Merkezi Müdürlüğü yöneticileri ve Buğday Islah Birimi çalışanlarına teşekkür ederim.

Kendal, E., Doğan, Y., \& Oral, E. 2016. Güneydoğu Anadolu Bölgesinde Arpa Yetiştiriciliğinin Sorunları ve Çözüm Önerileri. Türk Doğa ve Fen Dergisi, Bingöl Üniversitesi Fen Bilimleri Enstitüsü Dergisi, 2, 36-42.

Kendal, E., Karaman, M., Tekdal, S., \& Doğan, S. 2019. Analysis of pPromising Barley (Hordeum vulgare L.) Lines Performance by AMMI and GGE Biplot in Multiple Traits and Environment. Applied Ecology and Environmental Research, 17(2), 5219-5233.

Kendal, E., Tekdal, S., Aktaş, H., Karaman, M., Bereketoğlu, K., \& Doğan, H. 2014. Biplot Analiz Kullanılarak Yazlık arpa Genotiplerinin 
Verim ve Verim unsurlarının belirlenmesi. Trakya University Journal of Natural Sciences, 15(2), 95-103s.

Kendal, E. (2019). Comparing Durum Wheat Cultivars by Genotype× Yield× Trait and Genotype× Trait Biplot Method. Chilean journal of agricultural research, 79(4), 512-522.

Kılıç, H., Kendal, E., \& Aktaş, H. 2018. Evaluatıon of

Yield and Some Quality Characters of Winter barley (Hordeum vulgare L.) genotypes using biplot analysis. Agriculture \& Forestry, Vol. 64 Issue 3: 101-111.

Kılıç, H., Tekdal, S., Kendal, E., \& Aktaş, H. 2012. Augmented Deneme Desenine Dayalı İleri Kademe Makarnalık Buğday (Triticum turgidum ssp durum) Hatlarının Biplot Analiz Yöntemi ile Değerlendirilmesi. KSU Doğa Bil. Derg, 15(4), 18-25.

Kızılgeçi, F., M. Yıldırım., C. Akıncı and Albayrak, Ö. 2016. Bazı Arpa Genotiplerinin Diyarbakır ve Mardin Koşullarında Verim ve Kalite Parametrelerinin İncelenmesi. Iğdır Üni. Fen Bilimleri Enst. Dergisi, 6(3): 161-169.

Kizilgeci, F., Albayrak, O., Yildirim, M., \& Akinci, C. 2019. Stability Evaluation of Bread Wheat Genotypes Under Varying Environments by AMMI Model. Fresenius Environmental Bulletin, 28(9), 6865-6872.

Malik, R., Sharma, H., Sharma, I., Kundu, S., Verma, A., Sheoran, S., ... \& Chatrath, R. 2014. Genetic Diversity of Agro-morphological Characters in Indian Wheat Varieties Using
GT Biplot. Australian Journal of Crop Science, 8(9), 1266.

Mut, Z., Sirat, A., \& Sezer, İ. 2014. Samsun Koşullarında Bazı iki Sıralı Arpa (Hordeum vulgare conv. distichon) Genotiplerinde Tane Verimi ile Başlıca Tarımsal Özelliklerin Belirlenmesi ve Stabilite Analizi. Yüzüncü Y1l Üniversitesi Tarım Bilimleri Dergisi, 24(1), 60-69.

Oral, E., Kendal, E., Kilic H. and Dogan, Y. 2019. Evaluation Barley Genotypes in Multienvironment Trials by AMMI Model and GGE biplot Analysis. Fresenius Environmental Bulletin. Volume 28 - No. 4A/2019 pages 3186-3196.

Solonechnyi, P., Kozachenko, M., Vasko, N., Gudzenko, V., Ishenko, V., Kozelets, G., ... \& Vinyukov, A. 2018. AMMI and GGE Biplot Analysis of Yield Performance of Spring Barley (Hordeum vulgare L.) Varieties in Multi Environment Trials. Poljoprivreda i Sumarstvo, 64(1), 121-132.

Yan W, Fregeau-Reid J, Mountain N, Kobler J. 2019. Genotype and Management Evaluation Based on Genotype by Yield*Trait (GYT) analysis. Crop Breed Genet Genom. 2019;1:e190002. https://doi.org/10.20900/cbgg20190002

Yan W, Frégeau-Reid J. 2018. Genotype by Yield*Trait (GYT) Biplot: a Novel Approach for Genotype Selection Based on Multiple Traits. Sci Rep., (8):8242.

Yan, W., and I.R. Rajcan. 2002. Biplot Analysis of Test Sites and Trait Relations of Soybean in Ontario. Can. J. Plant Sci. 42:11-20. 